\title{
Impact of the subtropical mode water biogeochemical properties on primary production in the North Atlantic: New insights from an idealized model study
}

\begin{abstract}
A.-S. Krémeur, ${ }^{1}$ M. Lévy, ${ }^{1}$ O. Aumont, ${ }^{2}$ and G. Reverdin ${ }^{1}$
Received 17 October 2008; revised 26 March 2009; accepted 15 April 2009; published 17 July 2009.

[1] An idealized biophysical model of the North Atlantic was designed to investigate the setting and variability of the subtropical mode water (STMW) biogeochemical properties and its impact on surface primary production in the North Atlantic. The model solution first emphasizes that the exact timing of STMW formation versus the timing of the spring bloom is of primary importance for setting the STMW biogeochemical properties. The surface primary production reaches its maximum in March in the STMW formation region just before its subduction. Thus the spring bloom consumes nitrate at the surface before STMW subducts, and STMW leaves the upper layers depleted in nutrients and fueled in organic matter. This spring consumption explains the low nutrient content of STMW observed near its source region by J. B. Palter et al. (2005). Furthermore, the model suggests that STMW plays a key role in exporting dissolved organic matter (DOM) at subsurface. The spring bloom produces a significant amount of DOM sequestrated in the mode waters after its subduction. This large pool of DOM is then remineralized with time along the transit of STMW through the subtropical gyre. Consequently, the nutrient content of STMW increases as it moves away from its source region. Finally, the model shows also that STMW is very important in controlling primary production in the western boundary current (WBC) region. Indeed, STMW remains isolated from the surface along its trajectory within the subtropical gyre. It joins the mixed layer by obduction in the WBC region only. This nutrient-rich old STMW irrigates and fertilizes the euphotic zone primarily in the WBC and then spreads along the boundary between the two gyres by advection.
\end{abstract}

Citation: Krémeur, A.-S., M. Lévy, O. Aumont, and G. Reverdin (2009), Impact of the subtropical mode water biogeochemical properties on primary production in the North Atlantic: New insights from an idealized model study, J. Geophys. Res., 114, C07019, doi:10.1029/2008JC005161.

\section{Introduction}

[2] This study is focused on the biogeochemical properties of a particular water mass found in the subtropical gyre of the North Atlantic: the subtropical mode water [Worthington, 1959, 1976; McCartney, 1982]. The subtropical mode water (STMW) has two important characteristics: it occupies a large volume at subsurface and it is renewed by subduction south of the western boundary current (WBC) every year. STMW subducts at the end of each winter into the subtropical thermocline when the mixed layer begins to retreat [Worthington, 1959; Marshall et al., 1993; Hazeleger and Drijfhout, 2000; da Costa et al., 2005]. The STMW is called "mode water" [Masuzama, 1969] because it is found in a thick layer $(100-300 \mathrm{~m})$, nearly homogeneous in tempera-

\footnotetext{
${ }^{1}$ Laboratoire d'Océanographie et du Climat: Expérimentation et Approche Numérique, IPSL, Paris, France.

${ }^{2}$ Institut de recherche pour le Développement, Centre IRD de Bretagne, Plouzané, France.

Copyright 2009 by the American Geophysical Union. 0148-0227/09/2008JC005161
}

ture and salinity, above the main thermocline and under the mixed layer in the subtropical gyre. The STMW has been observed south of the Gulf Stream in the North Atlantic [Worthington, 1959; McCartney, 1982]. It is also referred to as the $18^{\circ} \mathrm{C}$ Water [Worthington, 1959].

[3] From a biogeochemical perspective, the STMW is important because it represents a thick subsurface reservoir of nutrients potentially available for the ecosystem. The biogeochemical role of STMW has been suggested recently from the compilation of various observations. In particular, the careful examination of two summer WOCE sections across the subtropical North Atlantic [Palter et al., 2005] revealed for the first time that STMW is nutrient-poor near the STMW formation region. They also suggest that this low nutrient signature persists more than $2,000 \mathrm{~km}$ to the south of the STMW source region despite the ongoing remineralization that occurs at depth. Palter et al. [2005] infer that this low nutrient signature is responsible in part for the low productivity of the subtropical gyre, especially on the western side. This conclusion stems from the analysis of two-dimensional data from the National Ocean Data Center and SeaWiFS images of surface chlorophyll 
(CHL). For these authors, the nutrient-poor STMW, found just below the surface in the western part of the subtropical gyre, potentially prohibits deep ocean rich nutrients from directly upwelling to the euphotic zone. Another potentially important characteristic of mode waters was raised by Mémery et al. [2005]. They point out that the subduction of mode waters has potentially a great importance on the export of organic matter and carbon, because mode waters remain isolated from the surface during long periods of time.

[4] The works of Palter et al. [2005] and of Mémery et al. [2005] raise three main questions. First, how are the STMW biogeochemical properties set during STMW formation? Second, can we identify changes in the STMW biogeochemical properties after STMW subduction? Third, what is the impact of STMW on PP in the subtropical gyre and more generally in the whole North Atlantic? To study the biogeochemical properties of STMW, we developed a coupled biophysical model of the circulation and ecosystem in the North Atlantic with idealized geometry and seasonal forcings. The model is integrated until the properties of STMW reach a mean state.

[5] The paper is organized as follows. The idealized biophysical model is first presented (section 2). Then, the physical and biological features of the simulation and mean climatological observations from the World Ocean Atlas [Locarnini et al., 2006; Antonov et al., 2006] are compared in order to assess the strengths and the limitations of our idealized model (section 3). The mechanism by which nitrate becomes depleted at the surface and dissolved organic matter (DOM) incorporated in STMW during STMW formation is first explored (section 4). Then the changes in the STMW biogeochemical properties is investigated (section 5). Finally we analyze the impact of STMW on PP on a basin scale, by artificially controlling nitrate within the newly formed STMW (section 6). This is followed by a discussion and a conclusion sections (sections 7 and 8).

\section{Method}

\subsection{Physical Model}

[6] An idealized biophysical model of the North Atlantic was designed and is presented in the following. The NEMO primitive equation ocean circulation model (available at http://www.locean-ipsl.upmc.fr/NEMO) [Madec, 2008] is used. The configuration consists of an idealized double gyre on the $\beta$ plane $(2,120 * 3,180 \mathrm{~km})$ that mimics the North Atlantic circulation with its western boundary current. It is adapted from the rectangular configuration developed by Hazeleger [1998] to study the subtropical mode water formation and its variability [Hazeleger and Drijfhout, 1998, 1999]. The basin is rotated with an angle of $45^{\circ}$ in order to capture the western boundary current with maximum length. The domain corresponds to a reduced version of the North Atlantic: It extends from $15^{\circ} \mathrm{N}$ to $50^{\circ} \mathrm{N}$ and from $85^{\circ} \mathrm{W}$ to $55^{\circ} \mathrm{W}$ with a grid spacing of $35 \mathrm{~km}$ in both directions. This eddy-permitting configuration will be referred to as the " $1 / 3^{\circ}$ configuration." The vertical grid has 31 nonuniform vertical levels whose thickness vary from approximately $5 \mathrm{~m}$ at the surface to $250 \mathrm{~m}$ near the bottom. A flat bottom is set at the last vertical level (roughly at $4 \mathrm{~km}$ depth) and the lateral boundaries are straight and closed. We use free slip conditions and a nonlinear friction is applied at the bottom. For simplicity, a bilinear equation of state is used where the density $\rho$ (in $\mathrm{kg} \mathrm{m}^{-3}$ ) is a function of temperature $T$ (in ${ }^{\circ} \mathrm{C}$ ) and salinity $S$ (in psu): $\rho=\rho_{0}(1-$ $(\alpha T-\beta S)$ ). Here $\beta=7.7 \times 10^{-4} \mathrm{~kg} \mathrm{~m}^{-3} \mathrm{psu}^{-1}$ and $\alpha=$ $2 \times 10^{-4} \mathrm{~kg} \mathrm{~m}^{-3} \mathrm{~K}^{-1}$ are the expansion coefficients for salinity and temperature, respectively, and $\rho_{0}=1020 \mathrm{~kg}$ $\mathrm{m}^{-3}$. The model uses a level coordinate system and has an implicit free surface treatment of the barotropic equations. The month and the year are fixed to 30 and 360 days, respectively. The model is forced analytically by a penetrative solar radiation, a Newtonian-type net heat flux, a fresh water flux and wind stress. All forcings vary zonally and seasonally. The timing of the forcings has been carefully implemented to reproduce the restratification of the water column, which is needed for the ecosystem model (see auxiliary material). ${ }^{1}$

\subsection{NNPZDDOM Biogeochemical Model}

[7] The approach here is to keep the model as simple as possible, yet to conserve enough structure so that the basic functioning of the ecosystem is retained. In particular we want the model to simulate the meridional and vertical distribution of nutrients and the ecosystem seasonal cycle in the North Atlantic. We use the LODYC Ocean Biogeochemical Simulation Tools for Ecosystem and Resources (LOBSTER) biogeochemical model [Lévy et al., 2001, 2005a] implemented in NEMO [Madec, 2008]. The biogeochemical component consists of six prognostic variables expressed in terms of their nitrogen content: nitrate $\left(\mathrm{NO}_{3}\right)$, ammonium $\left(\mathrm{NH}_{4}\right)$, phytoplankton $(\mathrm{P})$, zooplankton $(\mathrm{Z})$, detritus (D) and semilabile DOM. A difference to Lévy et al. [2005a] is that the remineralization terms have the same expression throughout the whole water column (see auxiliary material). This is preferable in the case of long integrations to maintain continuity in the decay rates between the euphotic and aphotic layers. The parameter values were tuned from parameters suitable for the northeast Atlantic [Lévy et al., 2005a] and some were modified to better fit biogeochemical characteristics in the entire North Atlantic, in particular the DOM remineralization rate (see auxiliary material for more details). The biophysical model is spun up until a satisfying quasi-steady state of the thermodynamics and biogeochemistry is achieved throughout the whole water column and especially in the thermocline waters. See auxiliary material for more details.

\section{Analysis and Validation of the Mean State}

[8] In this section, basic features of the model climatological cycle related to STMW are presented and compared with observations, in order to highlight the strengths and limitations of the idealized model. All simulated values analyzed are from the climatology constructed from the 10-year run after the spin up. Climatological data are from the World Ocean Atlas [Locarnini et al., 2006; Antonov et al., 2006]. See auxiliary material for a complementary view of the GYRE-LOBSTER configuration.

${ }^{1}$ Auxiliary materials are available in the HTML. doi:10.1029/ 2008JC005161. 
a) STMW thickness (in m)

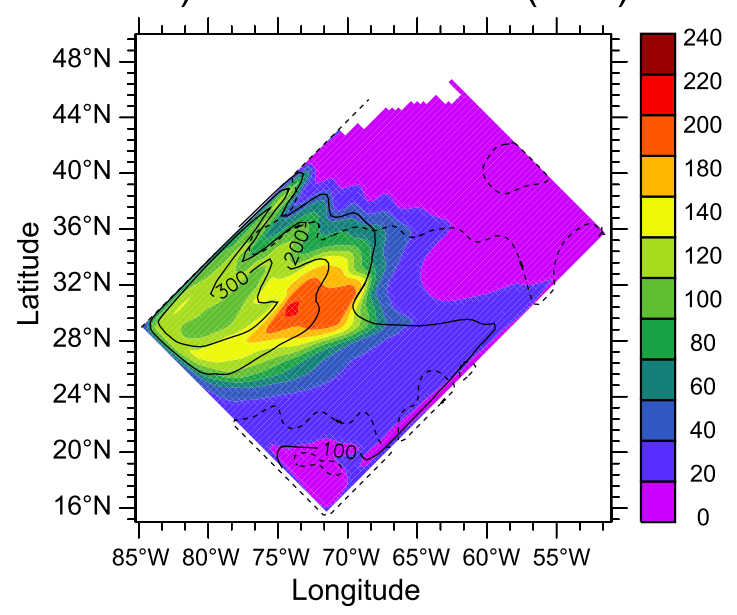

c) NO3 within STMW

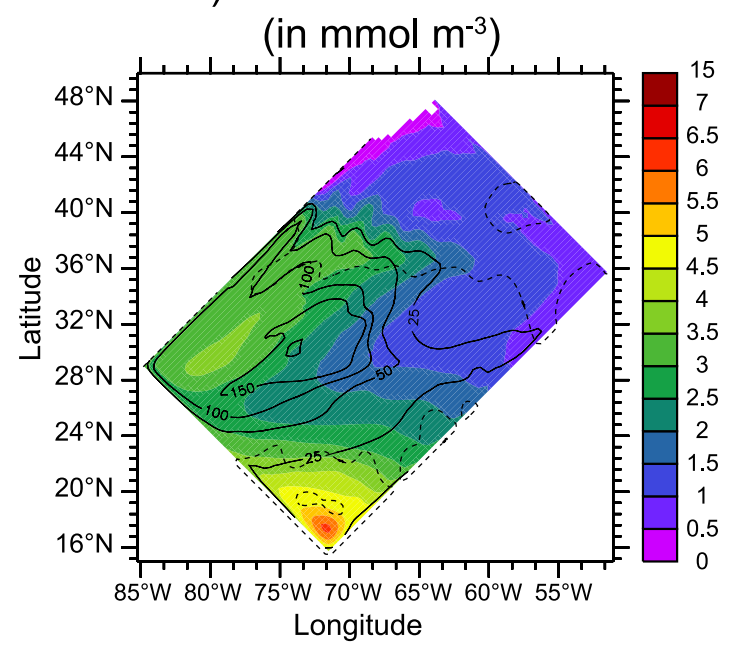

b) STMW thickness (in m)

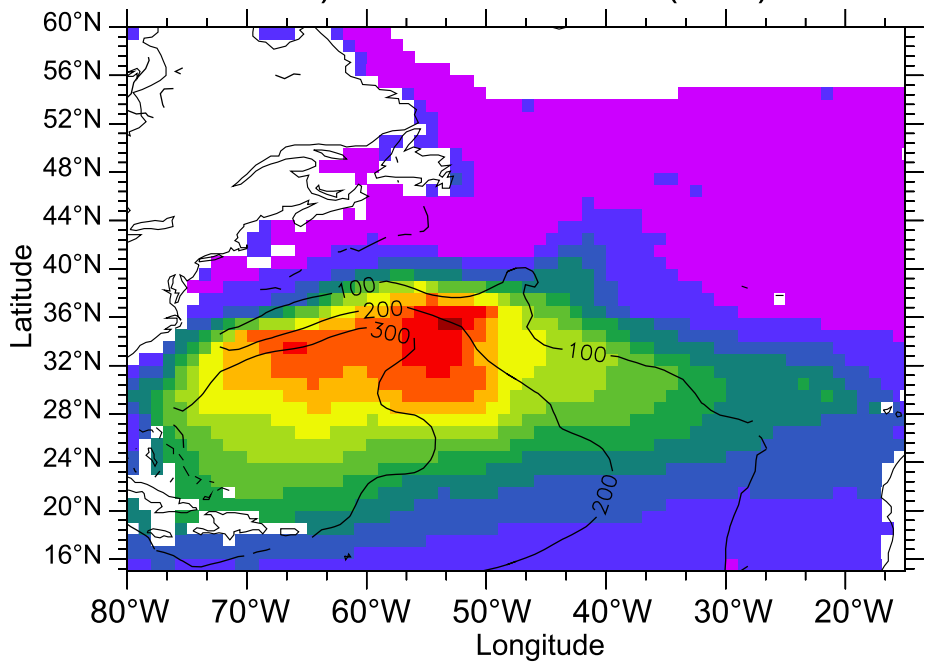

d) NO3 within STMW (in $\mathrm{mmol} \mathrm{m}^{-3}$ )

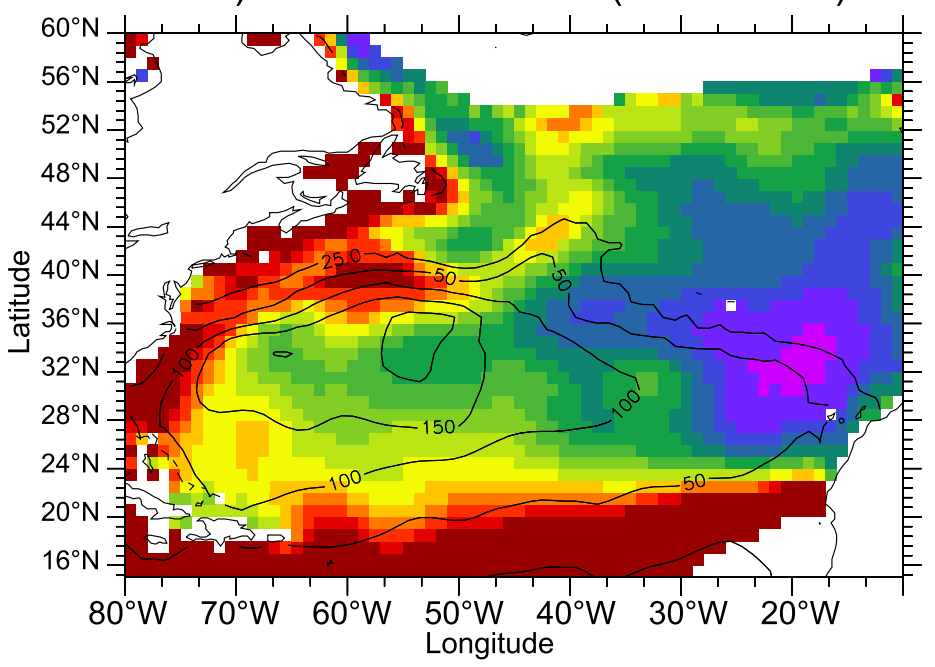

Figure 1. (left) Model and (right) data: (a) and (b) annual mean STMW thickness (in meters) with contours of the STMW core depth (in meters) and (c) and (d) annual mean nitrate within STMW (in mmol m $\mathrm{m}^{-3}$ ) with contours of the STMW thickness (in meters). The subtropical gyre is bounded by the zero contour of the barotropic stream function (see Figure S2) on the model solutions (Figures 1a and 1c). Hydrographic data are taken from the World Ocean Atlas [Locarnini et al., 2006; Antonov et al., 2006]. Nitrate data are taken from the World Ocean Atlas [Garcia et al., 2006].

\subsection{Physical Features of STMW}

\subsubsection{Identification of STMW in the Model}

[9] As mentioned before, STMW is characterized by a large volume of water with a minimal stratification (i.e., a minimum in the Brünt-Vaïsala frequency [McCartney, 1982] and a temperature close to $18^{\circ} \mathrm{C}$ [Worthington, 1959]). In the model these characteristics are encountered in the potential density range [24.5-24.8] (equivalent to $\left.1,024.5-1,024.8 \mathrm{~kg} \mathrm{~m}^{-3}\right)$. Note that this range is different in the real ocean, a discrepancy related to the use of a bilinear density equation: the model density range, when calculated with the UNESCO density equation, agrees with the observed range [26.35-26.55] [Palter et al., 2005]. In the following, we will always refer to the model STMW as the water mass within the [24.5-24.8] density range.

\subsubsection{Location and Thickness of STMW}

[10] Figures 1a and $1 \mathrm{~b}$ display the annual mean depth and thickness of STMW in the model and observations [Locarnini et al., 2006; Antonov et al., 2006]. In both model and data, STMW covers roughly the entire subtropical gyre. Its core is located in the western part of the gyre (Figure 1). The thickness of STMW reach values of up to $220 \mathrm{~m}$ in the northwestern part of the subtropical gyre (Figure 1a), which is consistent with data (Figure 1b). The depth of the core of STMW in the model reaches its maximum (approximately $300 \mathrm{~m}$ ) in the west (Figure 1). The core of STMW is slightly deeper (about $350 \mathrm{~m}$ ) in the data (Figure 1b). The simulated STMW resides between $24^{\circ} \mathrm{N}$ and $40^{\circ} \mathrm{N}$ (Figure 1a) while the observed STMW is slightly more extended in latitude, between $20^{\circ} \mathrm{N}$ and $40^{\circ} \mathrm{N}$ (Figure 1b). The simulated STMW 
a) Ventilation rate (in $\mathrm{m} \mathrm{yr}^{-1}$ )

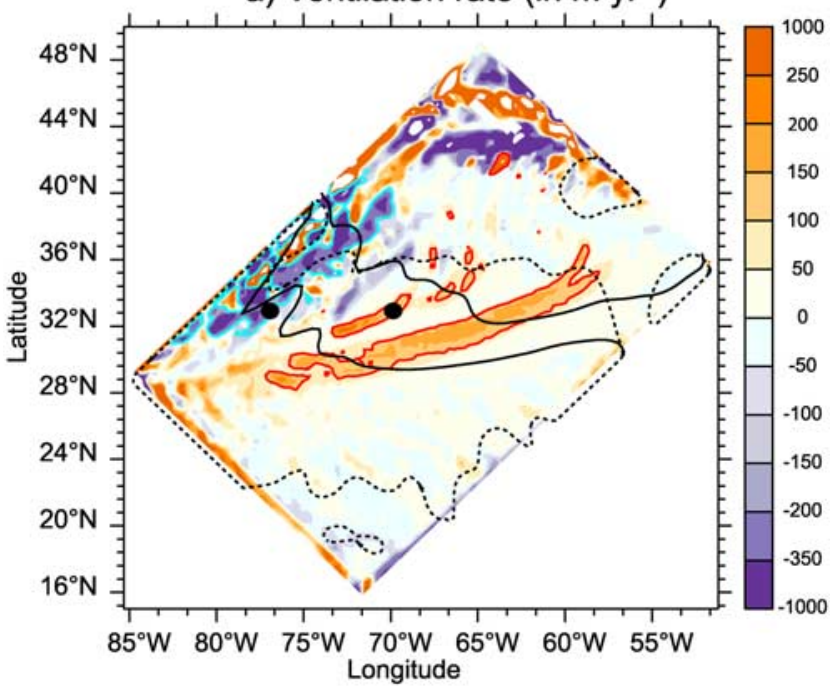

b) Currents within STMW (in $\mathrm{m} \mathrm{s}^{-1}$ )

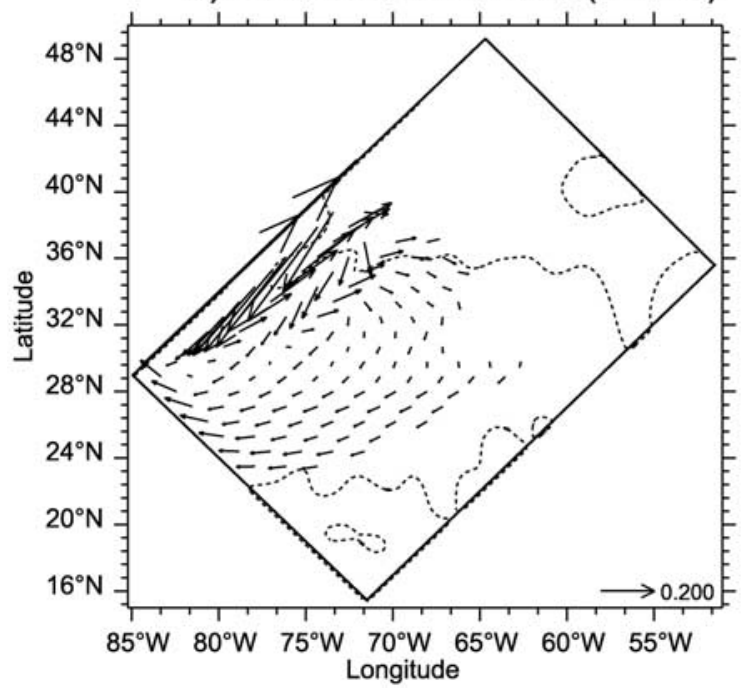

Figure 2. (a) Annual simulated ventilation rate (in $\mathrm{m} \mathrm{a}^{-1}$ ) with subduction and obduction represented by positive and negative values, respectively, and (b) mean currents within STMW (in m s${ }^{-1}$ ). Subduction rates larger than $100 \mathrm{~m} \mathrm{a}^{-1}$ are outlined by red contours. The 24.5 and 24.8 isopycnals that outcrop at the surface are also indicated to delimit the STMW formation region (solid black line). The black points indicate the positions of the two stations discussed in the text $\left(33^{\circ} \mathrm{N}, 77^{\circ} \mathrm{W}\right.$ and $\left.33^{\circ} \mathrm{N}, 70^{\circ} \mathrm{W}\right)$. The subtropical gyre is bounded by the zero contour of the barotropic stream function (see Figure S2).

core is also less extended in longitude. These drawbacks are due to the reduced size of the idealized model domain.

\subsubsection{Formation, Subduction, and Obduction} of STMW

[11] Ventilation is the process by which water mass is exchanged between the seasonal thermocline and the permanent thermocline. Practically, the annual ventilation rate is the net budget between subduction and obduction. Subduction is that part of the fluid detrained from the mixed layer into the permanent thermocline that is not reentrained elsewhere into the mixed layer within the same seasonal cycle [Stommel, 1979]. This process requires regions of large meridional mixed layer depth (MLD) gradient [Paillet and Arhan, 1996a, 1996b]. The inverse process where water from the permanent thermocline enters into the mixed layer is called obduction [Qiu and Huang, 1995] and sometimes induction [Williams et al., 2006].

[12] We use the kinematic method of Marshall and Marshall [1995] to estimate the annual ventilation rate and to identify the main areas of subduction and obduction of STMW in the model (see Appendix A for more details). The main subduction area is located in an elongated band south of the WBC (Figure 2a) in agreement with Worthington [1959], Warren [1972], McCartney [1982], and Woods [1985]. The subduction rate in this band ranges from $50 \mathrm{~m}$ $\mathrm{a}^{-1}$ to $200 \mathrm{~m} \mathrm{a}^{-1}$ (Figure 2a). The main obduction area is located in the WBC region (Figure 2a). Obduction rates reach values of $350 \mathrm{~m} \mathrm{a}^{-1}$. The patterns and amplitude of the subduction and obduction simulate the ventilation rates deduced from observations [Marshall et al., 1993]. The STMW formation region can be approximated by the intersection of the 24.5 and 24.8 isopycnals outcrops at the time of maximum MLD with the subduction area (Figure 2a). This formation region is found in the subtropical gyre between $30^{\circ} \mathrm{N}$ and $34^{\circ} \mathrm{N}$ and between $65^{\circ} \mathrm{W}$ and $75^{\circ} \mathrm{W}$ (Figure 2a). The STMW obduction zone is further west and situated between $30^{\circ} \mathrm{N}$ and $39^{\circ} \mathrm{N}$ and between $72^{\circ} \mathrm{W}$ and $80^{\circ} \mathrm{W}$ (Figure 2a).

[13] We now examine the lateral advection of STMW after its subduction in the model (Figure $2 \mathrm{~b}$ ). The STMW is advected with speeds from 2.5 to $4.9 \mathrm{~km} \mathrm{~d}^{-1}$ through the subtropical gyre (Figure 2b). This is consistent with estimations of roughly $4 \mathrm{~km} \mathrm{~d}^{-1}$ [Talley and Raymer, 1982; Hanawa and Yoritaka, 2001] from Panulirus station data $\left(32^{\circ} \mathrm{N}, 64^{\circ} \mathrm{W}\right)$. The model reproduces quite well the lateral advection of STMW. As a consequence, STMW finishes its loop through the subtropical gyre in 3-4 years in the model. This is faster than in the real ocean where the STMW recirculation takes $6-10$ years, because of the reduced size of the model domain.

[14] The seasonality of the formation of STMW is shown on Figure 3. The cross section of potential density displayed on Figure 3 clearly reveals that STMW is the thickest subsurface layer above the main thermocline, between the depths of 100 and $300 \mathrm{~m}$. STMW is also characterized by a minimum in the Brünt-Vaïsala frequency, i.e., a minimum in stratification $\left(<0.0510^{-2} \mathrm{~s}^{-2}\right.$, grey contours on Figure 3$)$. The typical bowl shape of the thermocline in the subtropical gyre is evident below the STMW. This cross section highlights the strong meridional MLD gradient in winter (Figure 3a), which is necessary for STMW formation. In winter (Figure 3a), STMW is in contact with the surface between $29^{\circ} \mathrm{N}$ and $36^{\circ} \mathrm{N}$ when the MLD is deep (Figures 2a and 3a). Between winter and summer, the mixed layer restratifies in response to seasonal warming (Figures 3a, $3 \mathrm{~b}$, and 3c). As a result, STMW is inducted laterally below the mixed layer and subducts progressively from winter to summer (Figures 3a and 3c). It remains isolated from the surface afterwards (Figures 3c and 3d). In autumn, STMW is entrained in the mixed layer in the north of the subtropical gyre (Figure 3d). To conclude, the simulated formation, 
a) Winter potential density at $72^{\circ} \mathrm{W}$

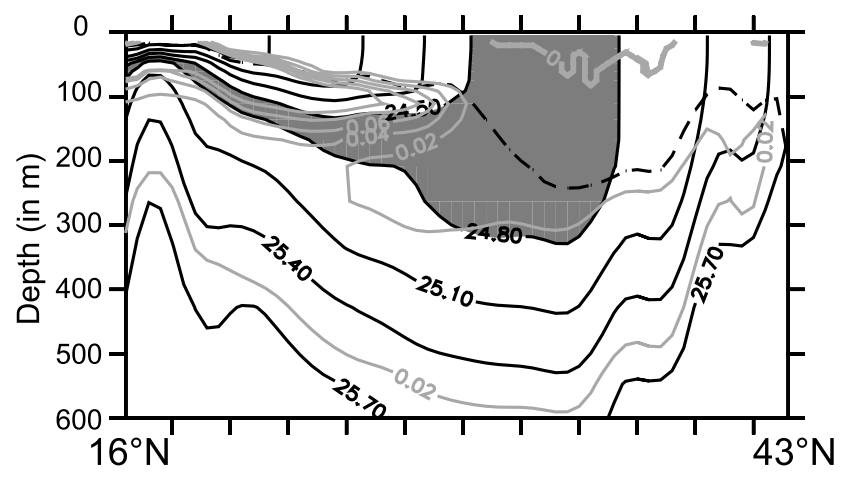

C) Summer potential density at $72^{\circ} \mathrm{W}$

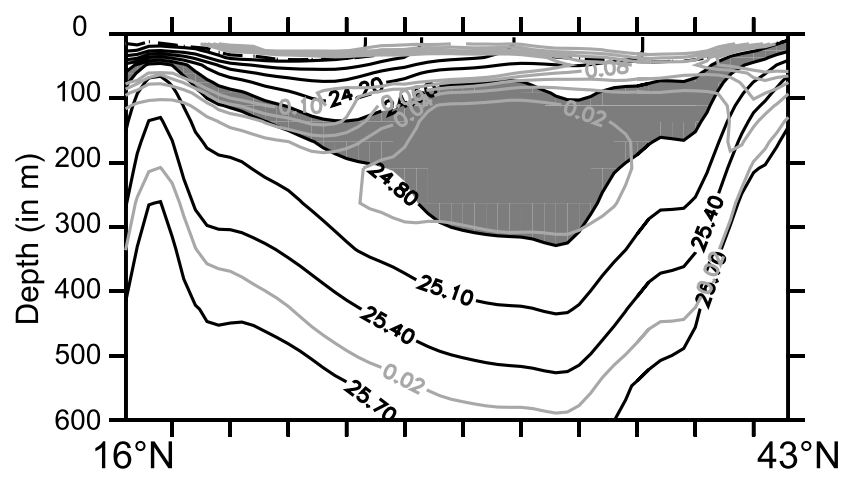

b) Spring potential density at $72^{\circ} \mathrm{W}$

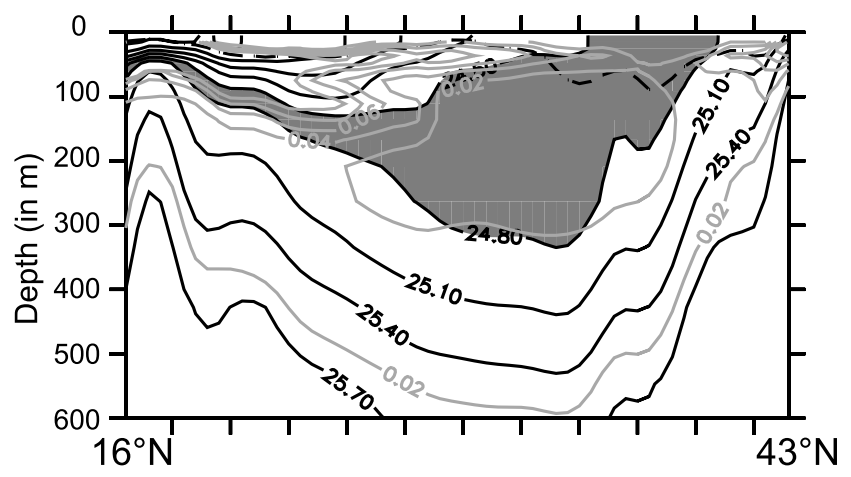

d) Autumn potential density at $72^{\circ} \mathrm{W}$

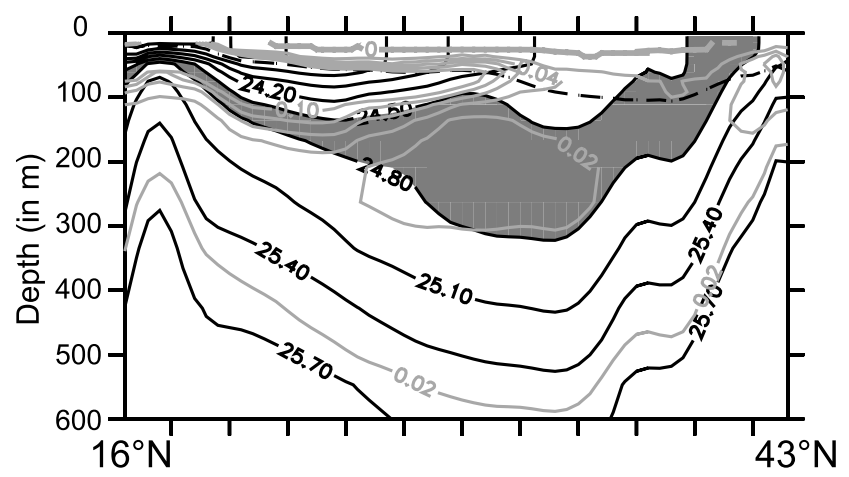

Figure 3. Cross section of simulated potential density at $72^{\circ} \mathrm{W}$ as a function of depth (in meters) and latitude between $16^{\circ} \mathrm{N}$ and $43^{\circ} \mathrm{N}$ in (a) winter, (b) spring, (c) summer, and (d) autumn. MLD is represented by the dashed black line, and the STMW density range is shaded (24.5-24.8). The BrüntVaïsala frequency is shown in lighter grey contours (in $10^{-2} \mathrm{~s}^{-2}$ ).

location, thickness, and vertical and lateral evolution of the STMW are coherent with observations.

\subsection{Biological Features of STMW}

\subsubsection{Nitrate Content of STMW}

[15] We now compare the annual mean simulated nitrate distribution to observations [Garcia et al., 2006] on the isopycnal level corresponding to STMW (Figure 1). Between $24^{\circ}$ and $40^{\circ} \mathrm{N}$, a zonal gradient in the nitrate concentration of STMW is present both in data and model. The observed nitrate content of STMW is low in the eastern part of the subtropical gyre with concentrations of 1.5 to $2 \mathrm{mmol} \mathrm{m} \mathrm{m}^{-3}$, and increases in the western part with values up to 5.5 to $6 \mathrm{mmol} \mathrm{m}^{-3}$ (Figure 1d). The model also shows two zonally different regions in the STMW: low values in the east, of the order of $1.5 \mathrm{mmol} \mathrm{m}^{-3}$, and high values in the west, of the order of 4.5 to $5 \mathrm{mmol} \mathrm{m}^{-3}$ (Figure 1c). The model does not capture the high concentrations ( 8 to $13 \mathrm{mmol} \mathrm{m}^{-3}$ ) of nitrate found between $15^{\circ} \mathrm{N}$ and $20^{\circ} \mathrm{N}$ along the WBC pathway. This observed signal is very likely the signature of nutrient-rich waters originating from the south and the equatorial region, following the geostrophic circulation through the WBC [Sarmiento et al., 2004; Williams et al., 2006]. These extreme values are not captured by the model because of its closed boundaries, which do not allow the simulation of water masses of remote origin. Note also the nitrate minimum in the far east of the subtropical gyre on Figure 1d. This minimum coincides very likely to Madeira mode water (MMW), which has the same density range than STMW [Siedler et al., 1987].

\subsubsection{Estimation of the Production of Nitrate in STMW}

[16] Figure 4 shows the annual simulated production of nitrate within STMW. In the model, this production is equal to the sum of the nitrification (the result of DOM remineralization) and of the degradation of the sinking particular organic matter. It varies from 0.60 to $0.20 \mathrm{mmol} \mathrm{m}^{-2} \mathrm{a}^{-1}$ within the subtropical gyre (Figure 4). Nitrate production reaches $0.37 \mathrm{mmol} \mathrm{m}^{-2} \mathrm{a}^{-1}$ at the model BATS station in the subtropical gyre. The simulated production of nitrate within STMW is in the range of previous values estimates from observations: $0.53 \pm 0.14 \mathrm{mmol} \mathrm{m}^{-2} \mathrm{a}^{-1}$ along the WOCE section [Palter et al., 2005], and $0.55 \pm 0.17 \mathrm{mmol}$ $\mathrm{m}^{-2} \mathrm{a}^{-1}$ at BATS [Bates et al., 2002].

[17] As shown in this section, this idealized $1 / 3^{\circ}$ configuration represents with reasonable accuracy the basin-scale patterns of the physical and biogeochemical properties of STMW. The model also captures the barotropic stream function, MLD, the meridional gradient of CHL and some basic features of the seasonal cycle of the MLD, nitrate and PP in the North Atlantic (see auxiliary material). However the small size of the domain restricts the range of validity of these simulations. STMW recirculates more rapidly through the subtropical gyre in the model (3-4 years instead of 610 years). Hence the timescale of the model has to be taken 


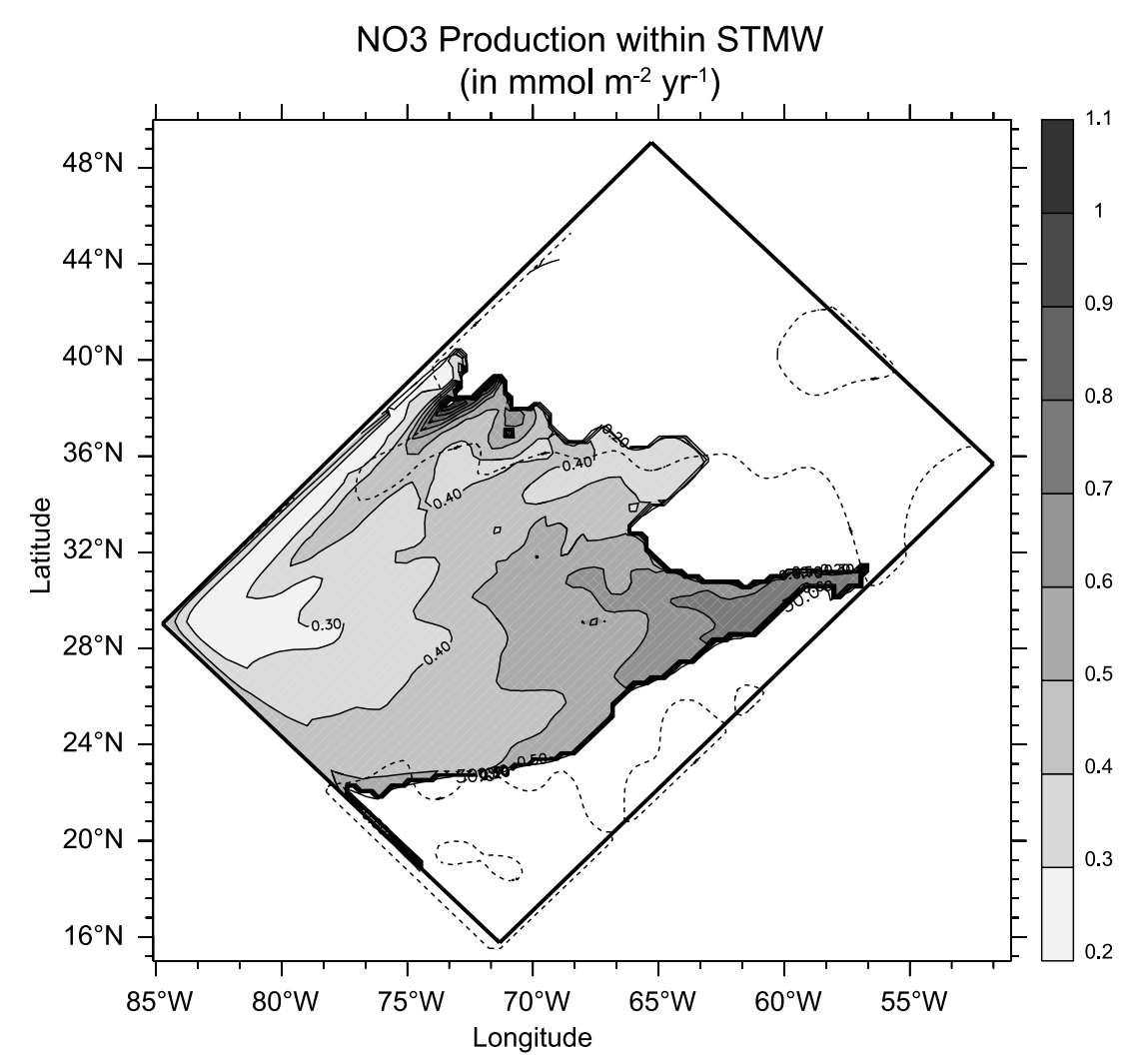

Figure 4. Production of nitrate within STMW in $\mathrm{mmol} \mathrm{m}^{-2} \mathrm{a}^{-1}$. The production of nitrate is the sum of the nitrification and of the degradation of sinking particular organic matter. The location of STMW is delimited by the $30 \mathrm{~m}$ contour of STMW thickness (black). Outside of this limit, the [24.5-24.8] interval is not considered as modal. The subtropical gyre is bounded by the zero contour of the barotropic stream function (see Figure S2).

with some caution in the following. Another consequence of the small size of the domain is that the center of the subtropical gyre is less isolated from the boundaries.

\section{Setting of the STMW Biogeochemical Properties During Ventilation}

[18] The model is used to assess the processes involved in the setting of STMW biogeochemical properties. As mentioned before, STMW is formed between winter and spring in the region where the 24.5 and 24.8 isopycnals outcrop (Figures $3 \mathrm{a}$ and $3 \mathrm{~b}$ ). We use the model to examine what processes set the STMW biogeochemical properties, in particular during this period.

\subsection{Biogeochemical Properties of Newly Formed STMW}

[19] We first examine how the nitrate distribution in the mixed layer evolves throughout winter and spring. Figure 5 shows the seasonal cycle of the surface nitrate and DOM at one station located over the STMW formation region, at $33^{\circ} \mathrm{N}, 70^{\circ} \mathrm{W}$ (Figure 2). At this station, the winter MLD reaches $230 \mathrm{~m}$ in March and the water column is fully restratified by mid-April (Figure 5a). Density does not change very much in the mixed layer during this period and stays in the density range of STMW (not shown). STMW outcrops at this station from mid-December to mid-May (Figure 5a). STMW is mostly detrained out of the mixed layer from the beginning of April until mid-April during the restratification of the water column (Figure 5a). Then STMW remains below the mixed layer till December, between $50-75 \mathrm{~m}$ and $250 \mathrm{~m}$.

[20] Nitrate at the surface increases from $0.5 \mathrm{mmol} \mathrm{m}^{-3}$ to $2 \mathrm{mmol} \mathrm{m}^{-3}$ from January to the end of February (Figure 5b), despite the ongoing new PP (NPP) (Figure 5c). At that time, the advection and diffusion of nitrate at the surface are greater than NPP (Figure 5c), which causes nitrate to increase in the mixed layer. From the beginning of March to mid-April, nitrate decreases strongly at the surface (Figure 5b). It is completely exhausted (less than $0.01 \mathrm{mmol}$ $\mathrm{m}^{-3}$ ) by mid-April by NPP. The important point is that nitrate exhaustion occurs before the end of STMW subduction at this station (Figure 5a).

[21] Another important characteristic of the STMW biogeochemical properties that emerges from the model solution is the important content of DOM in the STMW (Figure 5b). Indeed, DOM at the surface increases from February $\left(6.2 \mathrm{mmol} \mathrm{m}^{-3}\right)$ to mid-May $\left(7.5 \mathrm{mmol} \mathrm{m}^{-3}\right)$, contrary to surface nitrate at this station (Figure $5 \mathrm{~b}$ ). This shows that the dissolved organic nitrogen content of STMW is large compared to the dissolved inorganic one at the time of STMW formation.

\subsection{Timing of NPP With Respect to Subduction of STMW}

[22] Figure 5c shows that NPP based on nitrate consumption is maximum before STMW subduction $(5.25 \mathrm{mmol}$ 


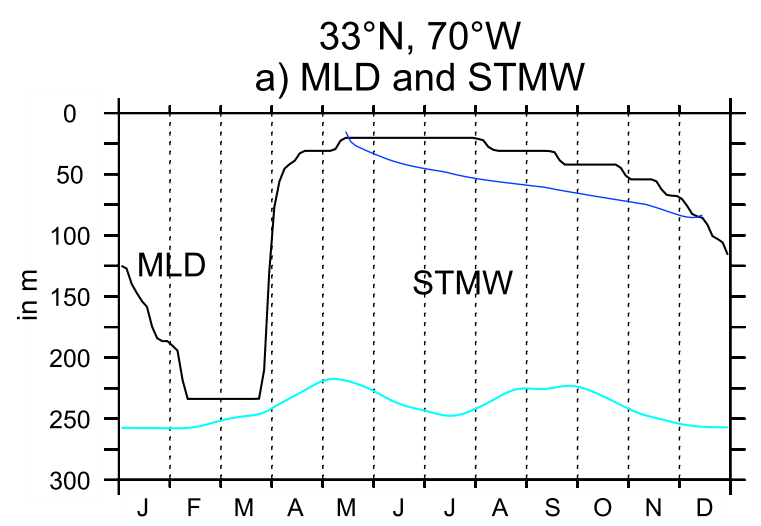

b) Surface concentrations

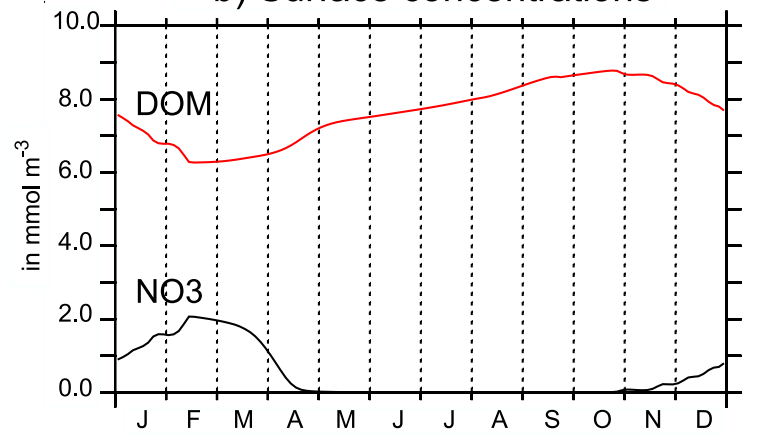

c) Surface trends

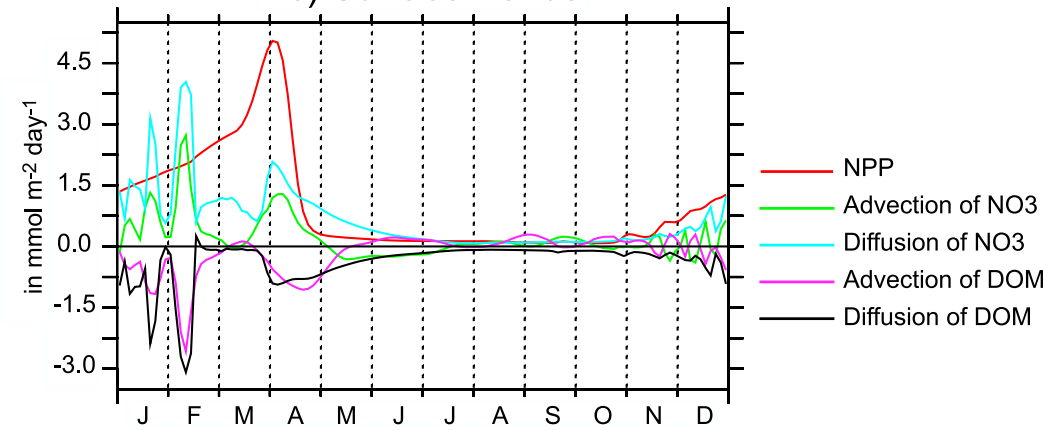

Figure 5. Seasonal cycle of surface tracers and trends in the STMW subduction region (located on Figure 2a) at $33^{\circ} \mathrm{N}, 70^{\circ} \mathrm{W}$ : (a) MLD and STMW depth (top in blue and bottom in turquoise) in meters, (b) tracers in mmol m${ }^{-3}$, and (c) new primary production (NPP) and physical trends in mmol m $\mathrm{m}^{-2} \mathrm{~d}^{-1}$ (integrated within the model biological layer). The STMW layer is bounded by the 24.5 and 24.8 isopycnals depths on Figure 5a.

$\left.\mathrm{m}^{-2} \mathrm{~d}^{-1}\right)$. The advection and diffusion of nitrate is rather low at the same period (less than $2 \mathrm{mmol} \mathrm{m}^{-2} \mathrm{~d}^{-1}$; Figure 5c). This results in exhaustion of surface nitrate before mid-April, in the STMW formation region. This also illustrates that NPP is of primary importance in setting the nitrate content of the newly STMW compared to the lower advection and diffusion trends (Figure 5c).

[23] We now examine the extent of the region where NPP is maximum before complete restratification of the water column. Figure 6 shows the timing of the NPP peak and the timing of the end of restratification (defined as the time where the MLD becomes minimum). The bloom is maximum in February and in March-April in the south and the north of the subtropical gyre, respectively. The subpolar bloom peak occurs in April-May (Figure 6a). The water column is completely restratified in April-May in the south of the subtropical gyre and in the whole subpolar gyre (Figure 6b). It is restratified later in May in the north of the subtropical gyre where STMW are formed (Figure 6b). This analysis confirms that the STMW formation region overlays a particular region where NPP is maximum before the complete restratification of the water column.

\section{Changes in the STMW Biogeochemical Properties After STMW Formation}

[24] In this section, we examine the spatial and seasonal variabilities of STMW biogeochemical properties. 
a) Months where NPP is maximum

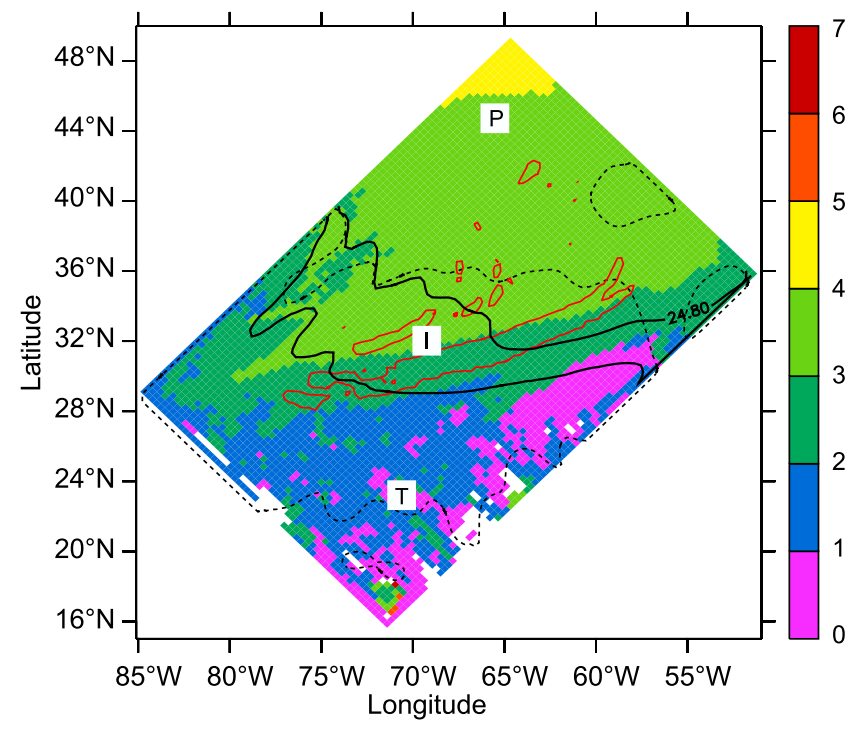

b) Months where the MLD is minimum

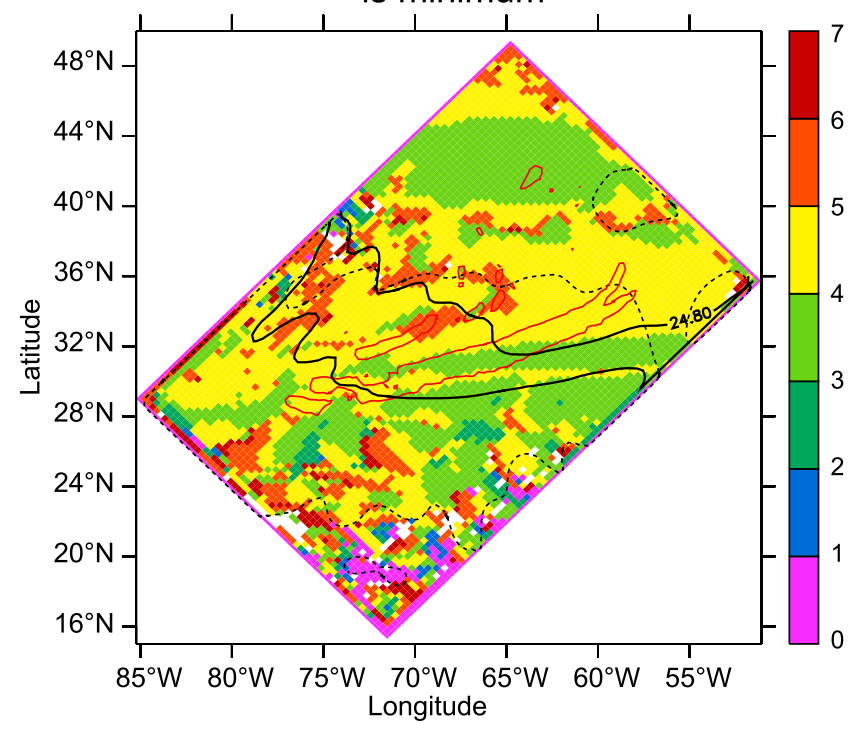

Figure 6. Coupling between restratification and the bloom peak: months where (a) NPP is maximum and (b) the MLD is minimum (0-1, January; 1-2, February, etc.). The subtropical (T), midlatitude (I), and subpolar (P) regions indicated on Figure 6a refer to areas analyzed in Figure 11. The subtropical gyre is bounded by the zero contour of the barotropic stream function (see Figure S2), and the subduction region is bounded by the red contours (Figure 2a). The 24.5 and 24.8 isopycnals that outcrop at the surface in winter are also indicated to delimit the STMW formation region (solid black line).

\subsection{Evidence of Spatial Variability in the STMW Biogeochemical Properties}

[25] Figure 7 exhibits the simulated nitrate and DOM concentrations of STMW in May, just after the subduction of the newly formed STMW. At that time, STMW is completely isolated from the surface. Nitrate is minimum in the STMW formation region $\left(0.5\right.$ to $1.5 \mathrm{mmol} \mathrm{m}^{-3}$; Figure 7a). Nitrate increases westward inside STMW from 1.5 to $4.5 \mathrm{mmol} \mathrm{m}^{-3}$ along its transit indicated by the currents (Figure 7a). DOM is maximum in the STMW formation region $\left(7.5 \mathrm{mmol} \mathrm{m}^{-3}\right.$; Figure $\left.7 \mathrm{~b}\right)$, and decreases along the transit of STMW (down to $4 \mathrm{mmol} \mathrm{m}^{-3}$; Figure $7 \mathrm{~b}$ ). The model solution presents an important east-west gradient of the STMW biogeochemical properties. More specifically, it shows a transfer in the nitrogen pool between the organic and the inorganic compounds along the transit of STMW from its source region to its obduction region (Figure 7).
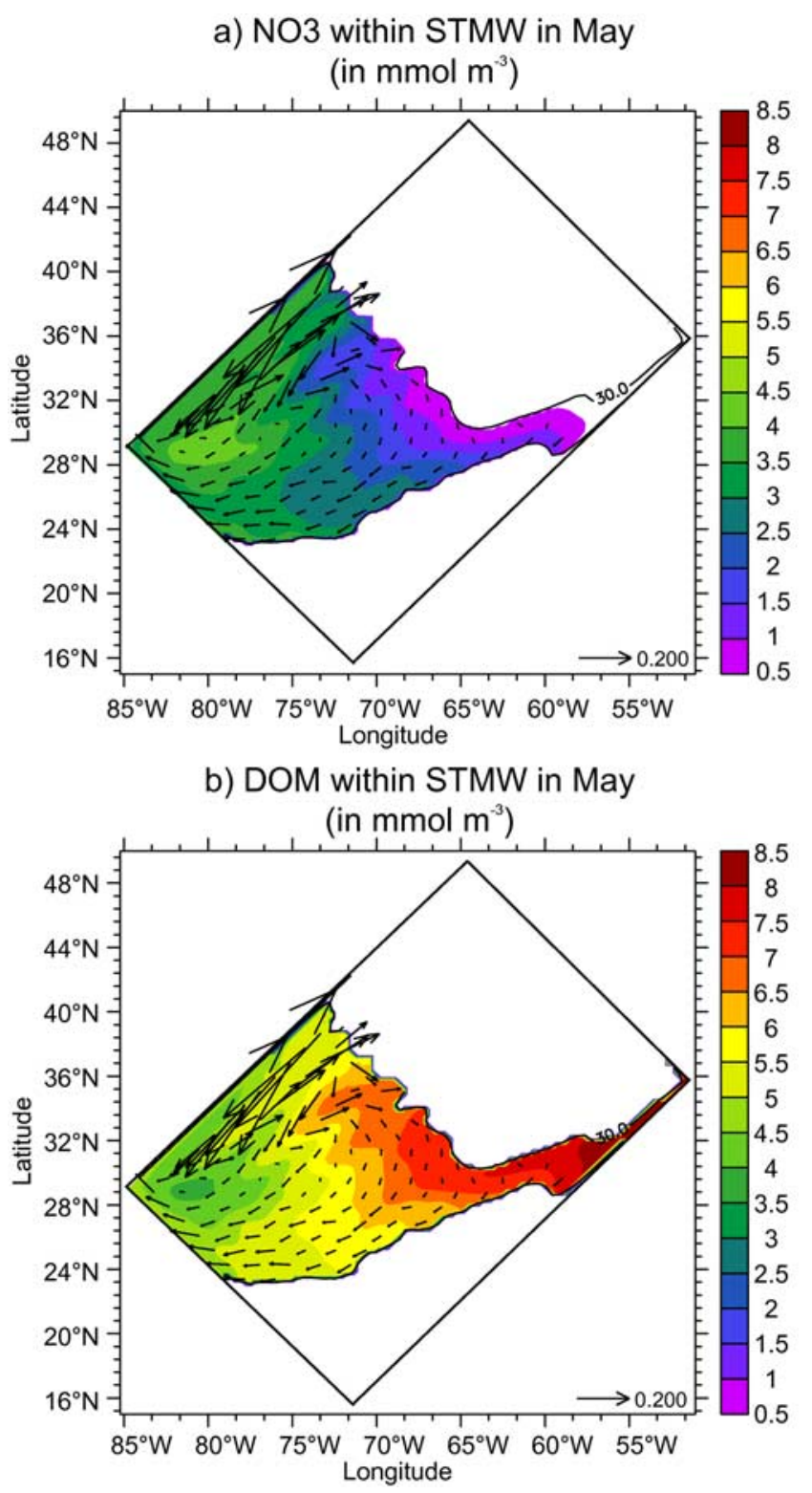

Figure 7. (a) Nitrate and (b) DOM within STMW in May (in $\mathrm{mmol} \mathrm{m}{ }^{-3}$ ). The location of STMW is delimited by the $30 \mathrm{~m}$ contour of STMW thickness (black). Outside of this limit, the [24.5-24.8] interval is not considered as modal. The currents $\mathrm{u}, \mathrm{v}$ within STMW are represented in $\mathrm{m} \mathrm{s}^{-1}$ (black arrows, Figure 2b). 


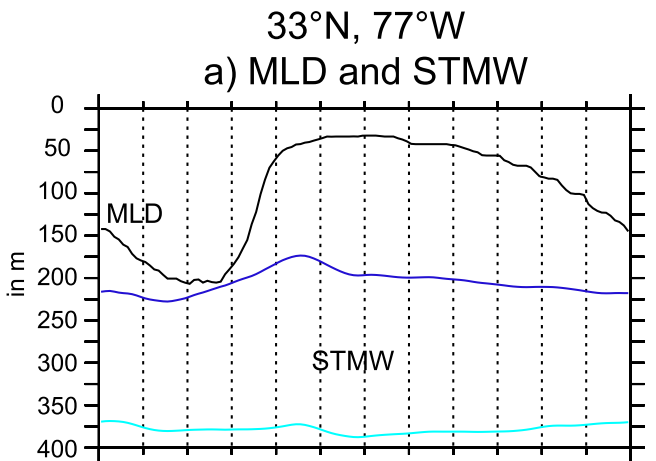

c) Tracers within STMW

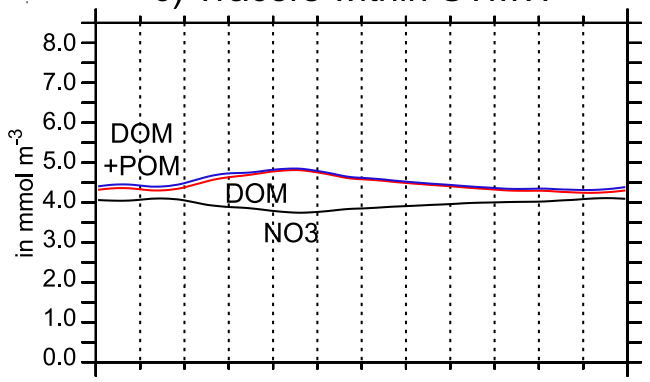

e) Trends of NO3 within STMW

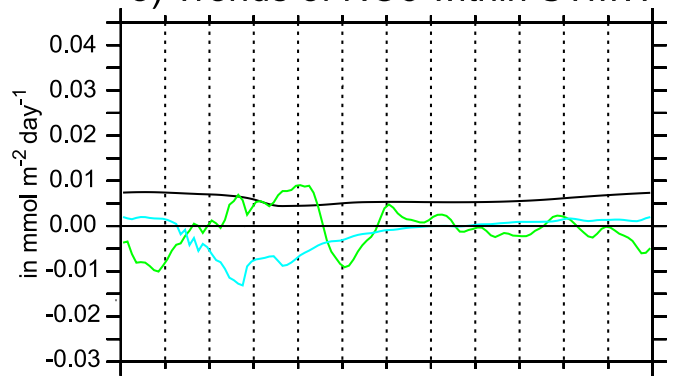

g) Trends of DOM within STMW

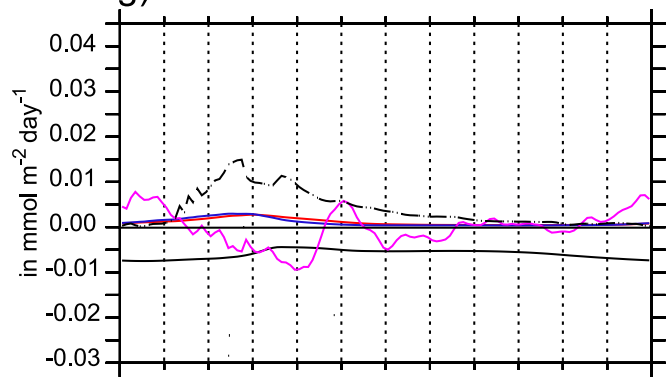

$33^{\circ} \mathrm{N}, 70^{\circ} \mathrm{W}$

b) MLD and STMW

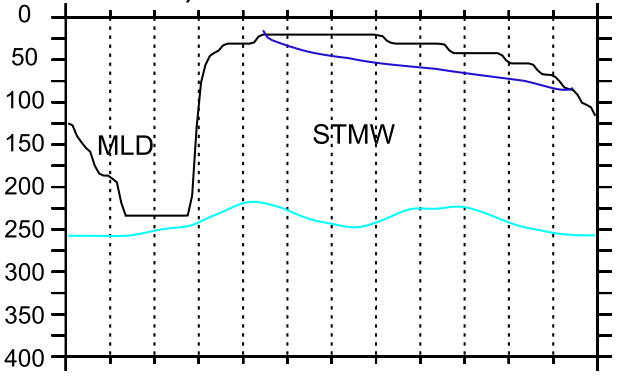

d) Tracers within STMW
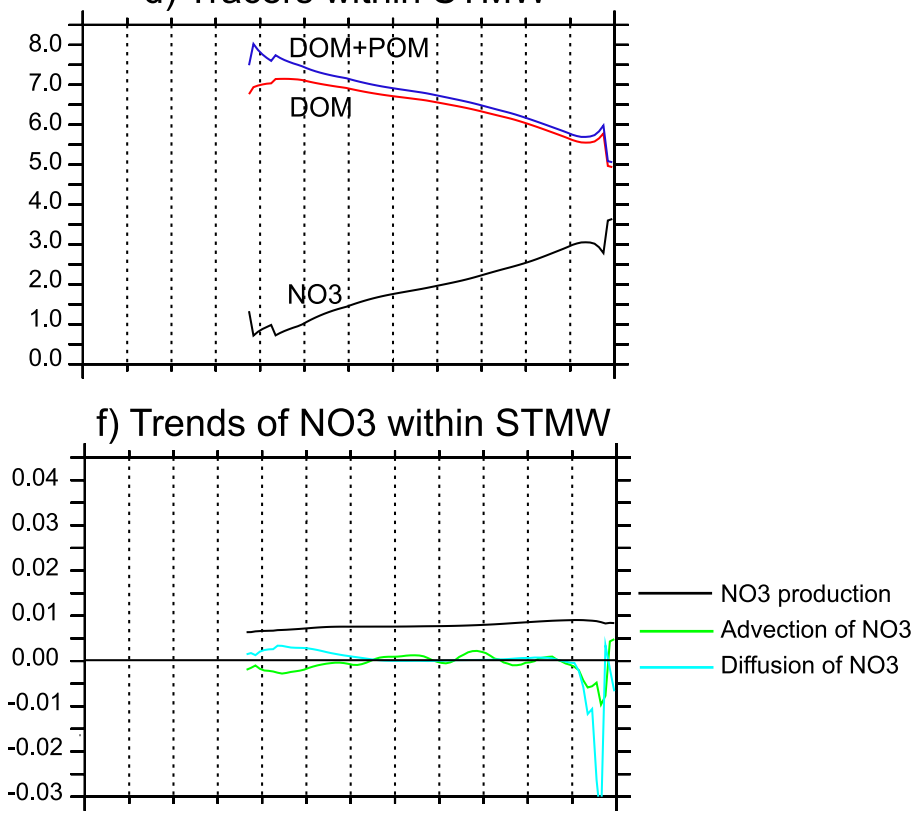

h) Trends of DOM within STMW

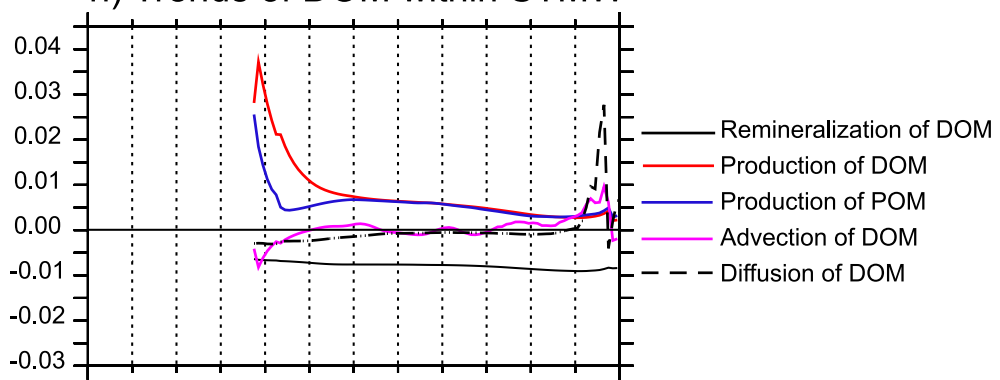

Figure 8. Seasonal cycle of tracers and trends within old STMW $\left(33^{\circ} \mathrm{N}, 77^{\circ} \mathrm{W}\right.$, south of the STMW obduction region, located on Figure $2 \mathrm{a})$ and young STMW $\left(33^{\circ} \mathrm{N}, 70^{\circ} \mathrm{W}\right.$, in the STMW subduction region): (a) and (b) MLD and STMW depth (top in blue and bottom in turquoise) in meters, (c) and (d) tracers within STMW in $\mathrm{mmol} \mathrm{m}{ }^{-3}$, (e) and (f) physical and biogeochemical trends of $\mathrm{NO}_{3}$, and (g) and (h) of DOM within STMW (integrated within the model biological layer) in mmol m $\mathrm{m}^{-2} \mathrm{~d}^{-1}$. The STMW layer is bounded by the 24.5 and 24.8 isopycnals depths on Figures $8 \mathrm{a}$ and $8 \mathrm{~b}$.

\subsection{Seasonal Cycles in the Formation Region and in the Obduction Region}

[26] We will now analyze in further details the seasonal cycles of tracers and associated trends in the STMW, at two stations along the $33^{\circ} \mathrm{N}$ latitude: one in the "young" STMW within the subduction region $\left(70^{\circ} \mathrm{W}\right)$ and one in the "old" STMW south of the obduction region $\left(77^{\circ} \mathrm{W}\right)$.
We refer to young STMW as STMW near its source region, and to old STMW as STMW near its obduction region. Figure 8 (right) shows the seasonal cycle of tracers and fluxes within STMW in the STMW formation region $\left(33^{\circ} \mathrm{N}\right.$, $70^{\circ} \mathrm{W}$, located on Figure 2a). The model highlights a strong evolution of the tracers content of STMW from May to December in the STMW formation region. STMW isopycnals outcrop there between mid-January and mid-April 


\section{CONTROL RUN}
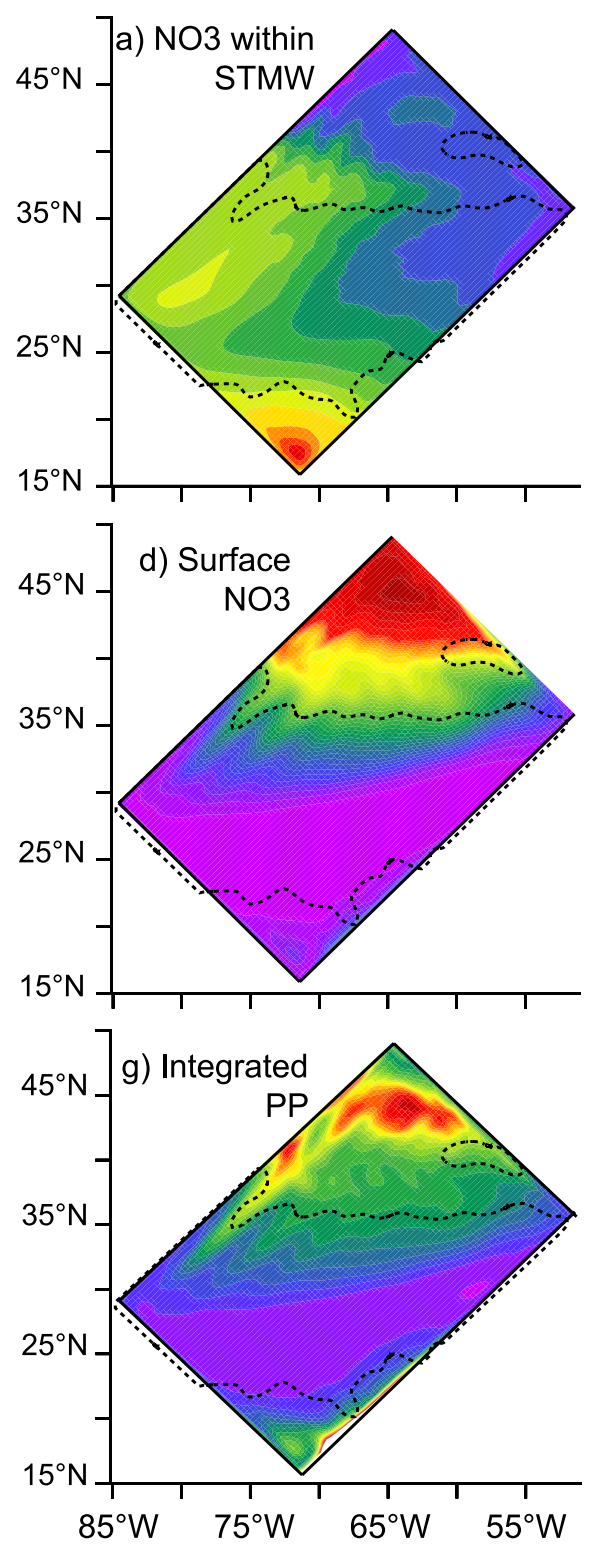

ANOMALY AFTER 2 YEARS

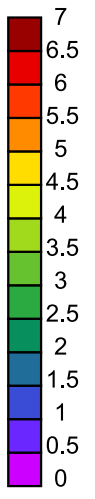

b) NO3 within
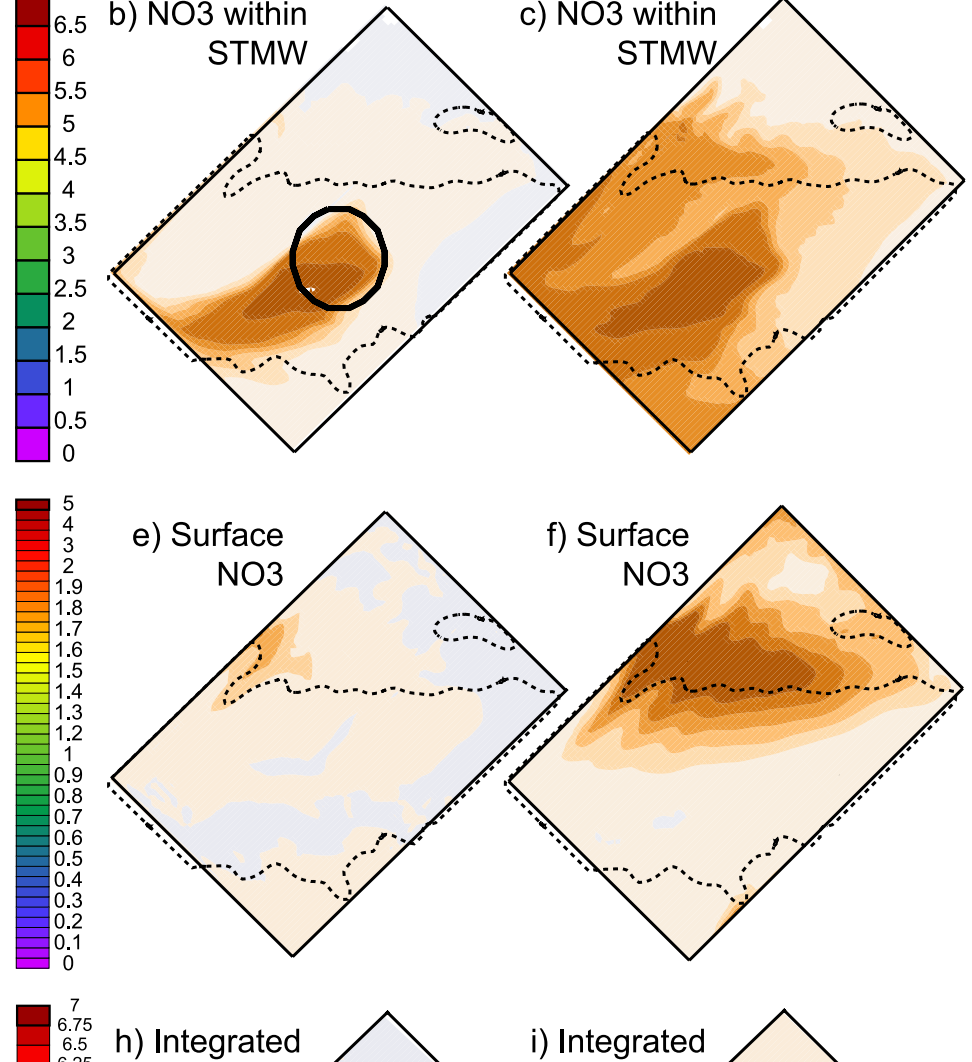
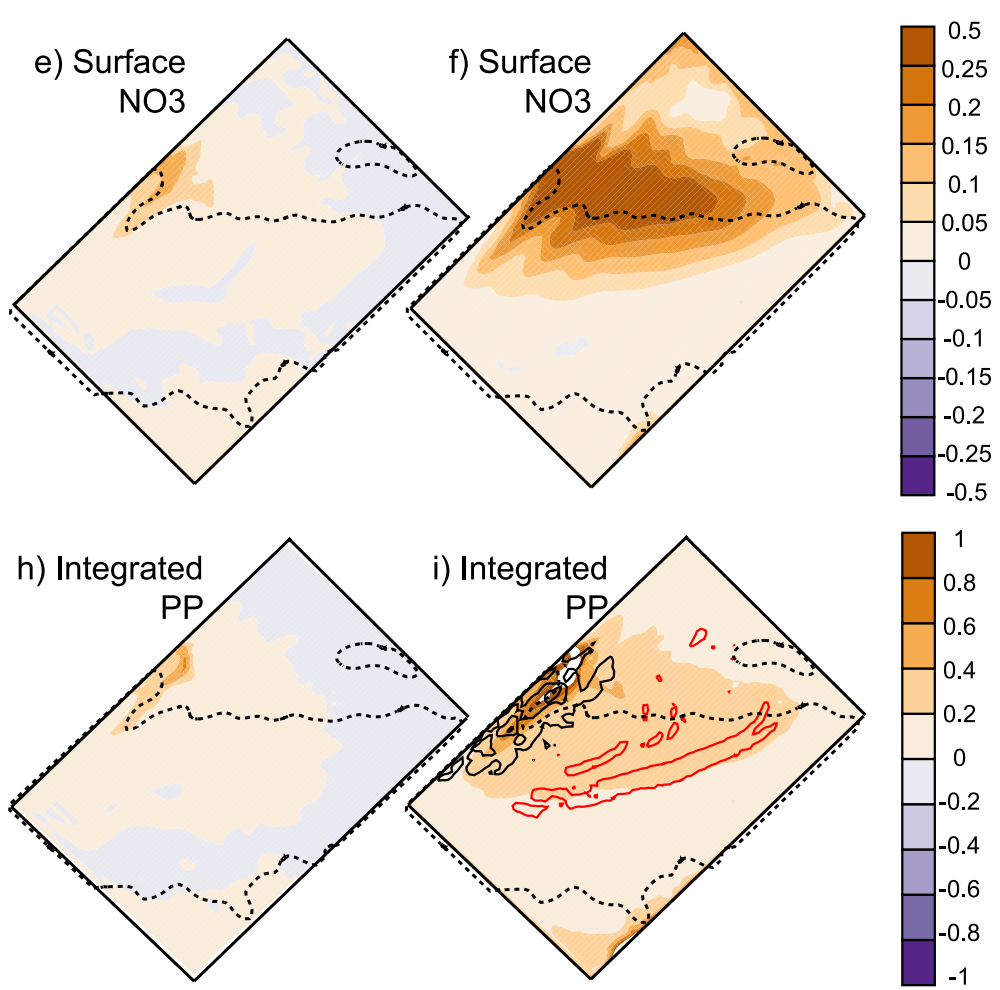

Figure 9. Results of the sensitivity experiment. (left) Annual mean patterns of (a) nitrate within STMW, (d) surface nitrate in mmol m $\mathrm{m}^{-3}$, and $(\mathrm{g})$ integrated total primary production in $\mathrm{mmol} \mathrm{m}^{-2} \mathrm{~d}^{-1}$ and corresponding anomalies after (middle) 2 years and (right) 10 years. The subtropical gyre is bounded by the zero contour of the barotropic stream function (see Figure S2). The area of injection is delimited by the black circle in Figure 9b. The red contours correspond to regions of subduction, and the black ones correspond to obduction in Figure 9i (from Figure 2a).

(Figures $8 \mathrm{~d}$ and $8 \mathrm{f}$ ). In May, STMW is depleted in nitrate (around $0.5 \mathrm{mmol} \mathrm{m}^{-3}$ ) and rich in DOM (around $7 \mathrm{mmol}$ $\mathrm{m}^{-3}$; Figure 8d). Then, nitrate within STMW increases from May to December while DOM decreases (Figure 8d). 80\% of the increase of nitrate results from the remineralization of DOM and of particulate organic matter $(\mathrm{POM})$ produced during the bloom (Figures $8 \mathrm{~d}$ and $8 \mathrm{~h}$ ). The other $20 \%$ is due to advection, mainly during summer (Figure $8 \mathrm{f}$ ).

[27] At the time of STMW subduction (from April to mid-May), the production of POM is strong (from 0.0375 to
$0.01 \mathrm{mmol} \mathrm{m} \mathrm{m}^{-2} \mathrm{~d}^{-1}$ ) (Figure $8 \mathrm{f}$ ). It is followed by the production of DOM from the degradation of POM which diminishes slowly (from a maximum of $0.035 \mathrm{mmol} \mathrm{m}^{-2}$ $\mathrm{d}^{-1}$, at the end of April) till July (Figure $8 \mathrm{f}$ ). The remineralization of DOM increases from -0.006 to $-0.012 \mathrm{mmol}$ $\mathrm{m}^{-2} \mathrm{~d}^{-1}$ from spring to autumn (Figure $8 \mathrm{~h}$ ). From July to October, the sinks of DOM are greater than its sources (Figure 8h), so that DOM decreases (Figure 8d). Remineralization of DOM is the main source of nitrate within STMW (Figure 8f). Advection and diffusion of nitrate and 
DOM are very low compared to biogeochemical terms from April to November (Figures $8 \mathrm{f}$ and $8 \mathrm{~h}$ ). Nevertheless, the advection and diffusion of nitrate are positive (Figure $8 \mathrm{f}$ ), which complements the increase of nitrate within STMW at this place in the formation region (Figure 8d). Note the high diffusion of nitrate (negative) and DOM (positive) when STMW joins the mixed layer in December (Figures $8 \mathrm{f}$ and $8 \mathrm{~h}$ ), which causes oscillations in nitrate (Figure $8 \mathrm{~d}$ ).

[28] Figure 8 (left) shows the seasonal cycle of tracers and fluxes within STMW south of the STMW obduction region $\left(33^{\circ} \mathrm{N}, 77^{\circ} \mathrm{W}\right.$, located on Figure $\left.2 \mathrm{a}\right)$. STMW is thus isolated from the surface all year long at this place (Figure 8a). The winter MLD reaches $200 \mathrm{~m}$ and the water column is restratified in May (Figure 8a). The top and the bottom of STMW do not vary much during the seasonal cycle and remain close to $225 \mathrm{~m}$ and $375 \mathrm{~m}$, respectively (Figure 8a). As a consequence, the concentrations of nitrate and DOM within STMW are fairly uncorrelated from the ones at the surface. A difference with the STMW found near the formation region is the less pronounced seasonal cycle of the STMW stocks (Figures $8 \mathrm{c}$ and $8 \mathrm{~d}$ ). The moderate increase of DOM and decrease of nitrate from the end of February to the beginning of April (Figure 8c) are due to the high diffusion of the tracers (Figures $8 \mathrm{e}$ and $8 \mathrm{~g}$ ), linked with the proximity of STMW with the mixed layer (Figure $8 \mathrm{a}$ ).

\section{Large-Scale Impact of STMW Biogeochemical Properties on Primary Production \\ 6.1. Sensitivity Experiment Description}

[29] A sensitivity experiment has been performed to localize and evaluate the basin-scale effect of STMW on PP. This experiment will be also used to visualize the STMW pathway through the subtropical gyre. A positive anomaly of nitrate $\left(6 \mathrm{mmol} \mathrm{m} \mathrm{m}^{-3}\right.$, which corresponds to the expected magnitude of interannual variability) [Palter et al., 2005] is injected within the newly formed STMW just after its subduction. The anomaly is injected from the end of May to the end of July at subsurface, with a relaxation timescale of 5 days. This injection doubles the mean level of nitrate at subsurface in this region (Figures 9a and 9b). The injection is repeated every year during 10 years. The sensitivity experiment is compared with the 10-year control run which was used to build the climatology and which has the same residual interannual internal variability of circulation and physical properties.

\subsection{Sensitivity Experiment Results}

[30] Figure 9 presents the anomaly of nitrate and PP in the sensitivity experiment with respect to the control run. After 2 years, the nitrate anomaly within STMW has started recirculating to the south of the subtropical gyre (Figure 9b). After 10 years, the anomaly has penetrated the entire subtropical gyre (Figure 9c). The injection induces a strong variation of the mean state of the STMW nitrate content, increasing in the mode water by $3 \mathrm{mmol} \mathrm{m}^{-3}$ near the region of injection and by $1 \mathrm{mmol} \mathrm{m}^{-3}$ at the BATS location and in the northern part of the subtropical gyre. Nitrate at the surface is very weakly affected after 2 years (Figure 9e). The surface nitrate anomaly appears mostly in the region of STMW obduction along the western boundary.
After 10 years, the surface nitrate anomaly has affected a much larger area, mainly in the subpolar gyre, but also on the flanks of the subtropical gyre (Figure 9f). Surface nitrate is not changed in the southern part of the subtropical gyre (Figure 9f).

[31] PP is affected after 2 years with a mean increase of roughly $0.2 \mathrm{mmol} \mathrm{m}^{-2} \mathrm{~d}^{-1}$ in the northwestern part of the subtropical gyre (Figure 9h). After 10 years, PP is increased in the north of the subtropical gyre by $1 \mathrm{mmol} \mathrm{m}^{-2} \mathrm{~d}^{-1}$ in the obduction region and by 0.2 to $0.4 \mathrm{mmol} \mathrm{m}^{-2} \mathrm{~d}^{-1}$ in the WBC pathway (Figure 9i). The results do not exhibit any change of PP in the southern part of the subtropical gyre (Figure 9i). Note that PP increases on the southeast corner which is an upwelling region (Figure 9i). The injection of nitrate is partly captured by the eastward stream in the south of the limited domain, but it does not affect the results in the interior. Figure 10 displays schematically the pathway of the nitrate anomaly within STMW and its effect on PP in \% after 10 years, in comparison to the mean state (Figure 9g). $\mathrm{PP}$ increases by $30 \%$ in the obduction region and by less than $15 \%$ in the $\mathrm{WBC}$ region (north of $30^{\circ} \mathrm{N}$; Figure 10 ). PP changes by less than $5 \%$ in the south of the subtropical gyre (south of $30^{\circ} \mathrm{N}$; Figure 10). In this sensitivity experiment, STMW does not appear as a major factor controlling PP through most of the subtropical North Atlantic.

\section{Discussion}

7.1. Importance of the Temporal Coupling Between STMW Subduction and the Bloom Peak in Setting the STMW Biogeochemical Properties

[32] Our idealized model suggests that the exact timing of STMW formation versus the timing of the spring bloom is of primary importance for the setting of the STMW biogeochemical properties. The peak of the spring bloom occurs in March to early April in the STMW formation region before the complete restratification of the water column. This results in a nearly complete depletion of nitrate in the mixed layer by phytoplankton biological utilization, before subduction of the new STMW. This spring consumption explains the low nutrient signature of STMW near its source region [Palter et al., 2005]. This particular midlatitude production regime has been previously identified by Lévy et al. [2005b] in the eastern part of the North Atlantic, on the basis of satellite data (SeaWiFS) combined with model MLD [Tréguier et al., 2003]. Indeed, the onset of the bloom depends on the relative depths of the critical depth $Z_{e}$ of the euphotic layer and the depth of the mixed layer [Sverdrup, 1953]. According to Lévy et al. [2005b], the midlatitude regime is found in regions where the winter MLD falls in the range $Z_{e}$ to $2 Z_{e}$. This is the case of the STMW formation region $\left(Z_{e} \simeq 100 \mathrm{~m}\right)$. This contrasts with the subpolar and subtropical regions where winter MLDs are much deeper and shallower than $Z_{e}$, respectively. The subpolar bloom occurs after restratification (Figure 11a). The reason for this feature is that NPP is weak in winter at high latitudes (Figure 11a) because of light limitation in a very deep mixed layer (more than 1,200 m; Figure 11a). This suggests that mode waters formed in subpolar regions may have different biogeochemical properties. 


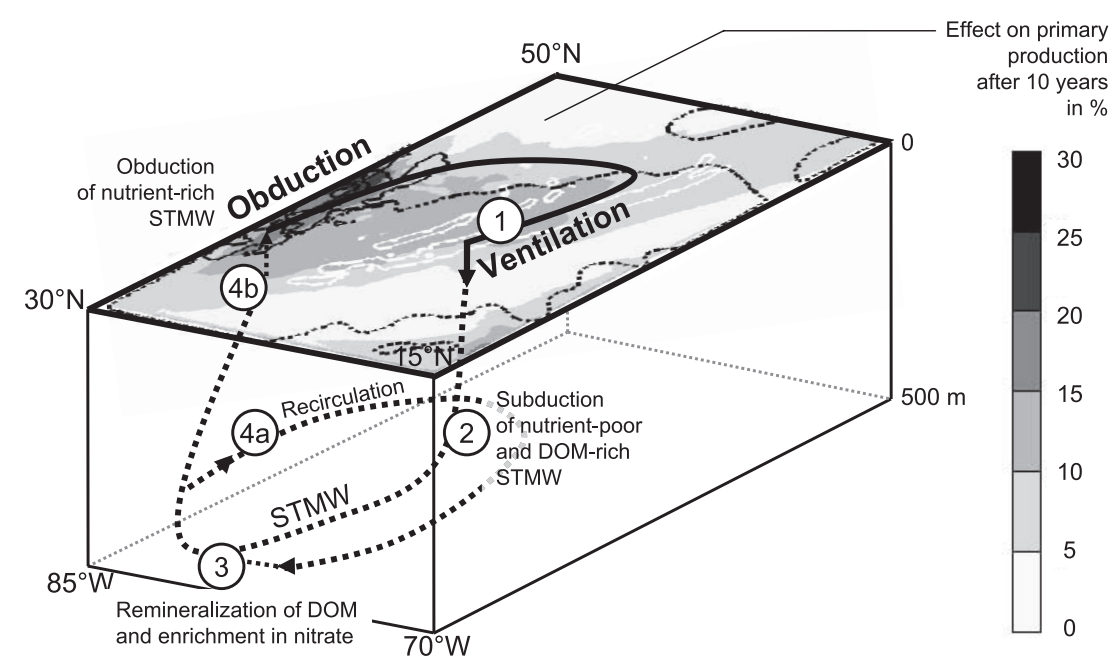

Figure 10. Schematic drawing of the effect of STMW on the total integrated primary production in percent adapted from Hazeleger and Drijfhout [2000]. The anomaly induced by STMW on primary production after 10 years at the surface is calculated from Figures $9 \mathrm{~g}$ and $9 \mathrm{i}$. The continuous line shows the pathway in the mixed layer and the dashed line beneath it (at subsurface). The subtropical gyre is bounded by the zero contour of the barotropic stream function (see Figure S2). The white contours correspond to regions of subduction, and the black ones correspond to regions of obduction (from Figure 2a).

\subsection{STMW Exportation of Dissolved Organic Matter and Its Remineralization on a Long Timescale}

[33] The model emphasizes that STMW plays a significant role in exporting DOM at subsurface. The biological activity in the midlatitude region induces the transformation of inorganic nutrients into organic compounds, before the water mass is isolated from the atmosphere. This results in a zonal gradient of STMW biogeochemical properties distribution: increase of nitrate together with decay of DOM along the trajectory of STMW within the subtropical gyre. This is in agreement with the WOCE section described by Palter et al. [2005] where the minimum of nitrate is confined between $31^{\circ} \mathrm{N}$ and $37^{\circ} \mathrm{N}$. The intensity of the zonal gradient is dependent on the choice of remineralization rate, which dictates the evolution of the DOM decay (not shown). In the model, the remineralization has been tuned to best fit the DOM distribution in the North Atlantic. The model suggests that DOM is essential in the STMW biogeochemical budget as advocated for the subtropical biogeochemistry by Rintoul and Wunsch [1991], Mahaffey et al. [2004], and Roussenov et al. [2006].

\subsection{Large-Scale Impact of STMW on Primary Production: Essentially in the WBC Region}

[34] Finally, the model suggests that STMW is very important in controlling PP in the WBC region. In this model, STMW does not control primary production in the whole subtropical gyre as hypothesized by Palter et al. [2005]. Indeed the model shows that STMW remains isolated from the surface along its trajectory within the subtropical gyre and joins the mixed layer by obduction in the western boundary current region. The nitrate anomaly is then advected by the WBC at the surface and toward the subpolar gyre. Hence the nutrient content of STMW does not cause the oligotrophy of the subtropical gyre as advocated by Palter et al. [2005].
[35] In this view, the effect of mesoscale and submesoscale processes on the tracers distribution cannot be neglected. Indeed mesoscale and submesoscale processes change the stratification and the vertical flux of nutrient to the surface layers [McGillicuddy et al., 1998]. The mesoscale structures are particularly abundant near the WBC, which corresponds to high eddy kinetic energy, but becomes sparser farther east [Palter et al., 2005]. This suggests that mesoscale structures would rather affect old STMW where nutrient are abundant. The mesoscale structures would then enhance NPP in this area, as suggested for a particularly intense structure by the data analysis of McGillicuddy et al. [2007]. McGillicuddy et al. [2007] have shown with data that a vertical advection of STMW nutrient is associated with a high NPP.

\subsection{Fertilization of the Euphotic Layers by STMW}

[36] We inferred form the model study that newly formed nutrient-poor STMW subducts and ventilates older nutrientrich mode water (scheme; Figure 10). The STMW is then laterally advected through the subtropics by the gyre's circulation, and is enriched in nitrate by the remineralization of DOM from year to year. After several years of circulation, only part of the nutrient-rich old STMW is inducted into the mixed layer within the nutrient stream in the WBC region. At the end of its travel, nutrient-rich old STMW irrigates and fertilizes the euphotic zone primarily in the WBC, and then spreads across the boundary between the two gyres by advection.

[37] What emerges from our results converges with the nutrient irrigation theory of Pelegri and Csanady [1991], Pelegri et al. [1996, 2006], and Williams et al. [2006]. Lévy [2005] linked the results of Palter et al. [2005] with the study of Williams et al. [2006]. Pelegri and Csanady [1991] and Pelegri et al. [1996, 2006] have highlighted how boundary currents provide an important transport of 
a) Subpolar production regime
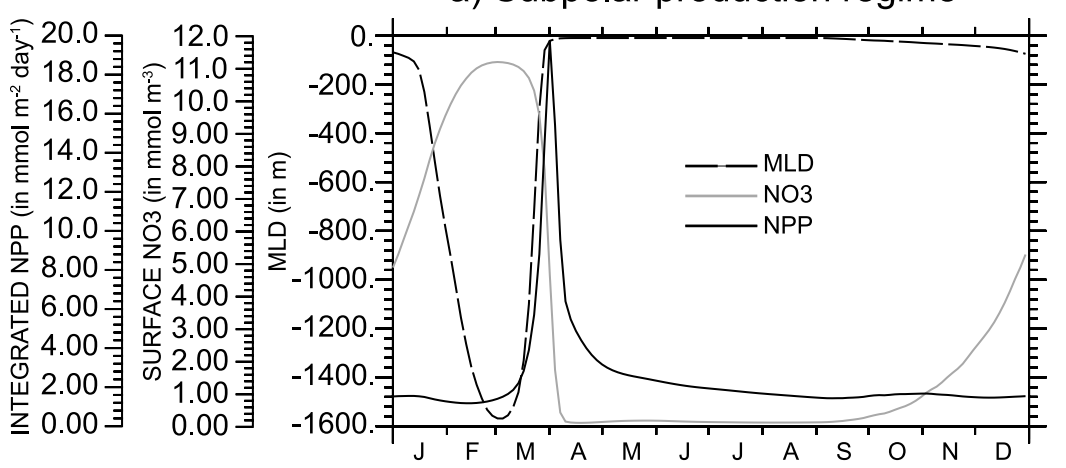

b) Mid-latitude production regime
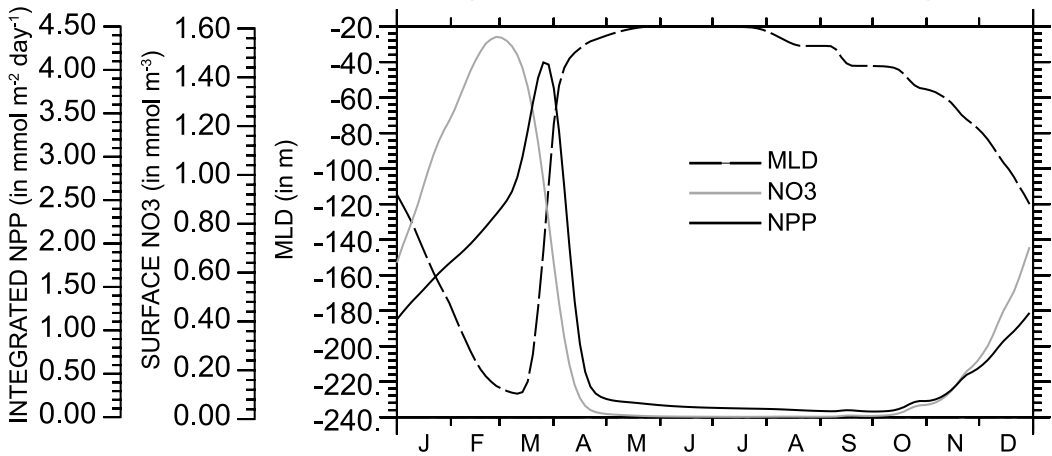

c) Subtropical production regime
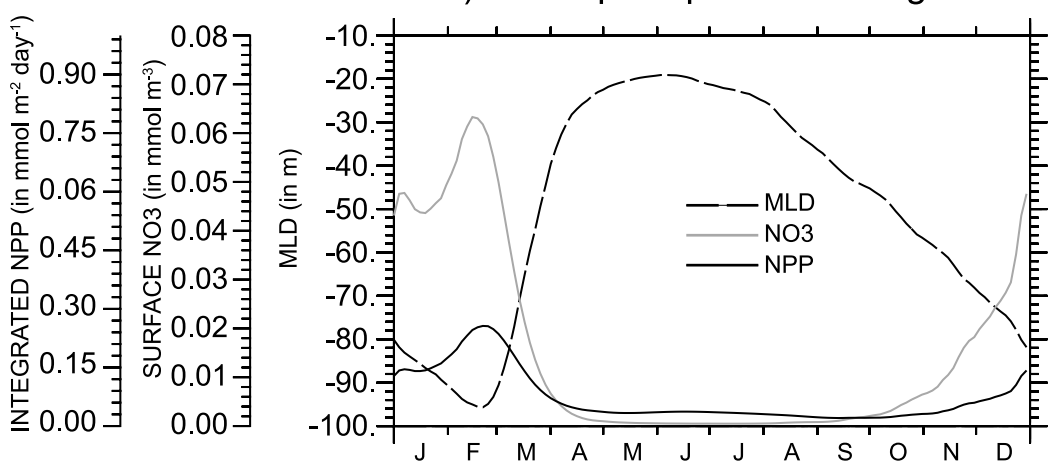

Figure 11. Seasonal cycle of MLD in meters (dash), surface nitrate in $\mathrm{mmol} \mathrm{m}^{-3}$ (grey), and integrated new primary production in $\mathrm{mmol} \mathrm{m} \mathrm{m}^{-2} \mathrm{~d}^{-1}$ (black) at three stations located on Figure 6a: the subtropical $(\mathrm{T})$, midlatitude (I), and subpolar $(\mathrm{P})$ regions. The bloom onsets are consistent with data analysis of Ueyama and Monger [2005].

nutrients in the upper layers of the oceans which sustain the levels of biological production at high latitudes. These studies demonstrate that boundary currents drive "nutrient streams," conduits of high nutrient flux which preferentially follow isopycnal surfaces in response to entrainment of thermohaline waters in the mixed layer. Jenkins and Doney [2003] underlined also the importance of diapycnal mixing within the Gulf Stream as a mechanism which transports nutrients to the upper layers, and hence sustains PP when these nutrient-rich layers recirculate in the thermocline of the subtropical gyre. Pursuing the work of Pelegri and Csanady [1991] and Pelegri et al. [1996], Williams et al. [2006] emphasize that mode waters are a primary cause for the high productivity in the western part of the North
Atlantic. Using climatological diagnostics over the North Atlantic, they found that nutrients are transferred in the WBC region from the nutricline into the winter mixed layer. At $36^{\circ} \mathrm{N}$, they evaluate that $40 \%$ of the nutrient stream is inducted into the mixed layer mainly by isopycnal advection while the other $60 \%$ recirculates in the thermocline of the subtropical gyre. They also used a numerical model which reveals that the nutrient stream sources are the nutrient-rich mode waters from the Southern ocean as advocated by Sarmiento et al. [2004], and the Tropics where significant remineralization occurs. The Gulf Stream has been shown to transport a total of $300 \mathrm{kmol} \mathrm{s}^{-1}$ nitrate at $24^{\circ} \mathrm{N}$ and more than $850 \mathrm{kmol} \mathrm{s}^{-1}$ at $36^{\circ} \mathrm{N}$ [Pelegri and Csanady, 1991]. About a quarter of this transport occurs on isopycnals within 
the density range of STMW between 25.6 and $26.5 \mathrm{~kg} \mathrm{~m}^{-3}$ [Williams et al., 2006]. Thus STMW corresponds to the lightest part of the nutrient stream. Also, the northward flux of DOM fed by nutrient streams is mainly driven by the STMW density range [Williams et al., 2006]. Besides, the WBC nutrient content does not increase along its length [Palter and Lozier, 2008]. The WBC is indeed fed by imported waters from the Tropics and the Southern ocean, as the nutrient-rich old STMW does. Note that the model does not capture these remote nitrate sources.

\section{Conclusions}

[38] The subtropical mode water, the $18^{\circ} \mathrm{C}$ water [Worthington, 1959], subducts at the end of each winter into the subtropical thermocline when the mixed layer begins to retreat [Worthington, 1959; Marshall et al., 1993; Hazeleger and Drijfhout, 2000; da Costa et al., 2005]. This water mass forms an important nutrient reservoir of the North Atlantic. The study is focused on the North Atlantic but can also be applied to STMW in the North Pacific [Hanawa and Yoritaka, 2001]. In this study, we present the model developed to investigate the STMW biogeochemical properties. We have analyzed how the biogeochemical properties of STMW are set during ventilation, how they changes and how they impact the surface layers on large scale.

[39] Model results have shown that (1) the exact timing of mode water formation versus the timing of the spring bloom is of primary importance for the setting of the mode water biogeochemical properties (in the North Atlantic, the STMW formation region is characterized by an early bloom onset and a long bloom duration, which produces lownitrate DOM-rich newly formed STMW); (2) the low nutrient content of STMW observed just south of the STMW formation [Palter et al., 2005] does not persist after STMW subduction (indeed, the dissolved organic nitrogen pool is remineralized in nitrate within mode water during STMW transit into the subtropical gyre); (3) the STMW biogeochemical properties affect primary production particularly in the western boundary current region where the mode water joins the surface; and (4) the nutrient-rich old STMW irrigates and fertilizes the euphotic zone in the WBC and the North Atlantic remotely.

[40] We have developed an idealized physical-biogeochemical coupled model. The analysis of the mean state shows that the model simulates reasonably well the circulation and biogeochemistry in both subtropical and subpolar areas of the North Atlantic (spatial patterns and seasonal cycle; auxiliary material). More specifically, the model reproduces the basin-scale patterns of the physical and biogeochemical properties of STMW: location, thickness, ventilation, nutrient content and nitrate production rate.

[41] However, the model and the approach we have used have limitations. The center of the gyre is closer to the boundary with the subpolar gyre and hence less isolated from intergyre Ekman transport than in the real ocean [Williams and Follows, 1998]. Also, waters recirculate more rapidly through the subtropical gyre, and the timescale set by the model geometry has to be taken with some caution. The closed boundaries do not allow the biogeochemical signatures of water masses of remote origins (like waters feeding the nutrient streams [Williams et al., 2006]). An important work will be to use a more realistic model setting to pursue our work, in particular to quantify the STMW supply of nitrate to the $\mathrm{WBC}$ region relative to remote sources. A further limitation is related to the intermediate resolution of the model, which marginally permits mesoscale eddies but suppress their generation by the sub-gridscale mixing. A natural continuation of this work will be to examine higher-resolution simulations $\left(1 / 9^{\circ}\right.$ and $\left.1 / 27^{\circ}\right)$ of the same model in order to test this hypothesis. In fact the time-dependent geostrophic flow consisting of eddies and meandering currents might be important in transferring properties between the gyres and between the WBC and the interior of the gyres. The model also lacks highfrequency forcing, which might also modify the exchanges between the gyres and between the surface and subsurface.

[42] Our results raise some insights on what sets the STMW biogeochemical properties on interannual and decadal scales. Palter et al. [2005] infer that the decadal variability of STMW formation remotely controls the decadal changes in subtropical primary production. More precisely, they suggest that cold winters characterized by deeper than normal mixed layer counterintuitively reduce new PP downstream of the STMW formation region (and the opposite effect for warm winters). This effect would be due to the enhanced formation of STMW, which are nutrient-poor and inhibit PP. However our study infers that if colder winter are associated with more STMW formation, they would not necessarily contain less nitrate. Indeed, a switch in production regime from midlatitude type to subpolar type is also expected with deeper MLDs. Consequently, the spring bloom will be shifted in time with respect to subduction and will not be able to exhaust the nutrient content of subducting waters anymore. It is thus expected that strongly nonlinear processes are in play on interannual timescales which cannot be simply ruled out.

\section{Appendix A: Kinematic Estimate of the Subduction and Obduction Rates}

[43] We will define some terms associated with the subduction process, and expose how the simulated ventilation rate is estimated in the model. Mass fluxes across the base of the mixed layer are conventionally named detrainment when the mixed layer losses water or entrainment in the opposite way. Although mixed layer detrainment takes place for a long period of the seasonal cycle, only a part of this period can be linked to subduction [Stommel, 1979; Woods, 1985; Cushman-Roisin, 1987]. This short period named the effective detrainment period diagnosed from climatological data is on the order of 1-2 months in winter for most of the North Atlantic subtropical gyre [Marshall et al., 1993]. The detrainment which occurs outside of this period will not be efficient. Therefore, subduction is that part of the detrained fluid that is not reentrained elsewhere in the mixed layer within the same seasonal cycle and remains in the permanent thermocline, also known as the Stommel's demon [Stommel, 1979]. The opposite process where the permanent thermocline looses water in favor of the seasonal thermocline is named obduction [Qiu and 
Huang, 1995] and sometimes induction [Williams et al., 2006]. The general process of water mass exchange between the seasonal thermocline and the permanent thermocline is called the ventilation.

[44] Here the kinematic estimate of ventilation rate of Marshall and Marshall [1995] is used. This method relies on a simplification of the detrainment rate calculation. The detrainment rate D (sometimes called the instantaneous subduction rate) has been defined as the downward velocity of a parcel fluid (following the horizontal motion of the parcel) relative to the base of the mixed layer [de Szoeke, 1980; Cushman-Roisin, 1987]:

$$
D=-\left(u_{m b} \cdot \nabla h_{m}+w_{m b}+\frac{\partial h_{m}}{\partial t}\right)
$$

[45] The detrainment rate is balanced by a lateral obduction through the sloping mixed layer $u_{m b}$. $\nabla h_{m}$ where $u_{m b}$ is the horizontal velocity of the particle at the base of the mixed layer, by a vertical velocity of the particle at the base of the mixed layer $w_{m b}$, and by a local change in mixed layer depth $\frac{\partial h_{m}}{\partial t}$. A basic way to determine the annual rate from equation (A1) is to follow a water column for 1 year and monitor the changes in mixed layer depth by detrainment and entrainment [Woods, 1985; Qiu and Huang, 1995].

[46] An alternative to this expensive Lagrangian method is to estimate the subduction rate from the annual volume flux across the deepest winter mixed layer base defining the permanent thermocline as a portion of the stratified column which is shielded from surface forcing throughout the year [Marshall and Marshall, 1995]. The annual subduction rate $\mathrm{S}_{\text {ann }}$ by the mean flow can be then approximated by equation (A2):

$$
S_{a n n}=-\left(u_{w} \cdot \nabla h_{w}+w_{w}\right)
$$

[47] The annual subduction rate $\mathrm{S}_{a n n}$ in $\mathrm{m} \mathrm{ya}^{-1}$ is estimated from the deepest mixed layer depth in the winter $h_{w}$ (Figure S3) which is the interface from the seasonal and permanent thermoclines, and from the annual mean horizontal and vertical velocities at the deepest mixed layer base $u_{w}$ and $w_{w}$. Note that $S_{a n n}$ is defined as subduction if positive and represents the volume per unit horizontal area per unit time at which permanent thermocline water is created from mixed layer water. The negative values of $\mathrm{S}_{a n n}$ corresponds to the obduction process. This simplification method provides a good approximation to the annual mass flux from the mixed layer to the permanent thermocline because it produces the observed large-scale pattern of the ventilation rate in the North Atlantic according to Hazeleger and Drijfhout [1999] and Marshall and Marshall [1995]. Furthermore, the ventilation rate is evaluated through the maximum MLD, which corresponds to the period of the efficient ventilation process. In the model, it is the lateral obduction term which dominates over the vertical flux and dictates subduction and obduction patterns (not shown). This is consistent with previous analysis of the ventilation rates in the North Atlantic [Marshall et al., 1993; Qiu and Huang, 1995]. It is worth noting, however, that vertical velocities in the model are slightly too weak, possibly because of the lack of bathymetry in the model. As $h_{w}$ is an Eulerian interface, this approach lacks the eddy contribution which may be important [Marshall, 1997; Hazeleger and Drijfhout, 2000] but is convenient for the " $1 / 3^{\circ}$ configuration" which marginally permits eddies.

[48] Acknowledgments. Financial support was provided by MERCATOR and INSU (LEFE/CYBER). We would like to thank the ESOPA support group and Ariane Koch-Larrouy for model support. A.-S. Krémeur is supported by a Ph.D. scholarship from the French Department of Research and by CNRS. Marina Lévy and Gilles Reverdin are supported by CNRS, and Olivier Aumont is supported by IRD.

\section{References}

Antonov, J. I., R. A. Locarnini, T. P. Boyer, A. V. Mishonov, and H. E. Garcia (2006), World Ocean Atlas 2005, vol. 2, Salinity, NOAA Atlas NESDIS, vol. 62, edited by S. Levitus, 182 pp., NOAA, Silver Spring, $\mathrm{Md}$.

Bates, N. R., A. C. Pequinet, R. J. Johnson, and N. Gruber (2002), A shortterm sink for atmospheric $\mathrm{CO}_{2}$ in subtropical mode water of the North Atlantic Ocean, Nature, 420, 489-493

Cushman-Roisin, B. (1987), Dynamics of the Oceanic Surface MixedLayer, edited by P. Muller and D. Henderson, Hawaii Inst. of Geophys., Honolulu.

da Costa, M., H. Mercier, and A.-M. Tréguier (2005), Effects of the mixed layer time variability on kinematic subduction rate diagnostics, J. Phys. Oceanogr., 4, 427-443.

de Szoeke, R. A. (1980), On the effects of horizontal variability of wind stress on the dynamics of the ocean mixed layer, J. Phys. Oceanogr., 10, $1439-1454$.

Garcia, H. E., R. A. Locarnini, T. P. Boyer, and J. I. Antonov (2006), World Ocean Atlas 2005, vol. 4, Nutrients (Phosphate, Nitrate, Silicate), NOAA Atlas NESDIS, vol. 64, edited by S. Levitus, 396 pp., NOAA, Silver Spring, Md.

Hanawa, K., and H. Yoritaka (2001), North Pacific sutropical mode waters observed in long XBT cross sections along the $32.5^{\circ} \mathrm{N}$ line, J. Oceanogr, $57,679-692$.

Hazeleger, W. (1998), Variability in mode water formation on the decadal time scale, Ph.D. dissertation, Univ. of Utrecht, Utrecht, Netherlands.

Hazeleger, W., and S. S. Drijfhout (1998), Mode water variability in a model of the subtropical gyre: Response to anomalous forcing, J. Phys. Oceanogr., 28, 266-288.

Hazeleger, W., and S. S. Drijfhout (1999), Stochastically forced mode water variability, J. Phys. Oceanogr., 29, 1772-1786.

Hazeleger, W., and S. S. Drijfhout (2000), Eddy subduction in a model of the subtropical gyre, J. Phys. Oceanogr., 30, 677-695.

Jenkins, W. J., and S. C. Doney (2003), The subtropical nutrient spiral, Global Biogeochem. Cycles, 17(4), 1110, doi:10.1029/2003GB002085.

Lévy, M. (2005), Nutrients in remote mode, Nature, 437, 628-631.

Lévy, M., P. Klein, and A. M. Treguier (2001), Impacts of sub-mesoscale physics on phytoplankton production and subduction, J. Mar. Res., 59, $535-565$.

Lévy, M., M. Gavart, L. Mémery, G. Caniaux, and A. Paci (2005a), A fourdimensional mesoscale map of the spring bloom in the northeast Atlantic (POMME experiment): Results of a prognostic model, J. Geophys. Res., 110, C07S21, doi:10.1029/2004JC002588.

Lévy, M., Y. Lehahn, J.-M. André, L. Mémery, H. Loisel, and E. Heifetz (2005b), Production regimes in the northeast Atlantic: A study based on Sea-viewing Wide Field-of-view Sensor (SeaWiFS) chlorophyll and ocean general circulation model mixed layer depth, J. Geophys. Res., 110, C07S10, doi:10.1029/2004JC002771.

Locarnini, R. A., A. V. Mishonov, J. I. Antonov, T. P. Boyer, and H. E. Garcia (2006), World Ocean Atlas 2005, vol. 1, Temperature, NOAA Atlas NESDIS, vol. 61, edited by S. Levitus, 182 pp., NOAA, Silver Spring, Md.

Madec, G. (2008), NEMO Ocean Engine, Note Pole Modél., vol. 27, Inst. Pierre-Simon Laplace, Paris.

Mahaffey, C., R. G. Williams, G. A. Wolff, and W. Anderson (2004), The physical supply of nutrients to phytoplankton in the Atlantic, Global Biogeochem. Cycles, 18, GB1034, doi:10.1029/2003GB002129.

Marshall, D., and J. C. Marshall (1995), On the thermodynamics of subduction, J. Phys. Oceanogr., 25, 138-151.

Marshall, J. C. (1997), Subduction of water masses in an eddying ocean, J. Mar. Res., 55, 201-222.

Marshall, J. C., A. J. G. Nurser, and R. G. Williams (1993), Inferring the subduction rate and period over the North Atlantic, J. Phys. Oceanogr., $23,1315-1329$. 
Masuzama, J. (1969), Subtropical mode water, Deep Sea Res., 16, $463-$ 472.

McCartney, M. S. (1982), The subtropical recirculation of mode waters, J. Mar. Res., 40, 427-464.

McGillicuddy, D. J., A. R. Robinson, D. A. Siegel, H. W. Jannasch, R. Johnson, T. D. Dickey, J. McNeil, A. F. Michaels, and A. H. Knapp (1998), Influence of mesoscale eddies on new production in the Sargasso Sea, Nature, 394, 263-266.

McGillicuddy, D. J., et al. (2007), Eddy/wind interactions stimulate extraordinary mid-ocean plankton blooms, Science, 316, 1021-1026.

Mémery, L., G. Reverdin, J. Paillet, and A. Oschlies (2005), Introduction to the POMME special section: Thermocline ventilation and biogeochemical tracer distribution in the northeast Atlantic Ocean and impact of mesoscale dynamics, J. Geophys. Res., 110, C07S01, doi:10.1029/ 2005JC002976.

Paillet, J., and M. Arhan (1996a), Shallow pycnoclines and mode water subduction in the eastern North Atlantic, J. Phys. Oceanogr., 26, 96-114.

Paillet, J., and M. Arhan (1996b), Oceanic ventilation in the eastern North Atlantic, J. Phys. Oceanogr., 26, 2032-2052.

Palter, J. B., and M. S. Lozier (2008), On the source of Gulf Stream nutrients, J. Geophys. Res., 113, C06018, doi:10.1029/2007JC004611.

Palter, J. B., M. S. Lozier, and R. T. Barber (2005), The effect of advection on the nutrient reservoir in the North Atlantic subtropical gyre, Nature, 437, 687-692.

Pelegri, J. L., and G. T. Csanady (1991), Nutrient transport and mixing in the Gulf Stream, J. Geophys. Res., 96, 2577-2583.

Pelegri, J. L., G. T. Csanady, and A. Martins (1996), The North Atlantic nutrient stream, J. Oceanogr., 52, 275-299.

Pelegrí, J. L., A. Marrero-Díaz, and A. W. Ratsimandresy (2006), Nutrient irrigation of the north atlantic, Prog. Oceanogr., 70, 366-406.

Qiu, B., and R. X. Huang (1995), Ventilation of the North Atlantic and North Pacific: Subduction versus obduction, J. Phys. Oceanogr., 25, 2374-2390.

Rintoul, S. R., and C. Wunsch (1991), Mass, heat, oxygen and nutrient fluxes and budgets in the North Atlantic, Deep Sea Res., Part A, 38 , suppl. 2, S355-S377.

Roussenov, V., R. G. Williams, C. Mahaffey, and G. A. Wolff (2006), Does the transport of dissolved organic nutrients affect export production in the Atlantic Ocean?, Global Biogeochem. Cycles, 20, GB3002, doi:10.1029/ 2005GB002510.
Sarmiento, J. L., N. Gruber, M. Brezinski, and J. P. Dunne (2004), Highlatitude controls of thermocline nutrients and low latitude biological productivity, Nature, 427, 56-60.

Siedler, G., A. Kuhl, and W. Zenk (1987), The Madeira mode water, J. Phys. Oceanogr., 17, 1561-1570.

Stommel, H. (1979), Determination of water mass properties of water pumped down from the Ekman layer to the geostrophic flow below, Proc. Natl. Acad. Sci., U. S. A., 76, 3051-3055.

Sverdrup, H. U. (1953), On conditions for the vernal blooming of phytoplankton, J. Conseil, 18, 287-295.

Talley, L. D., and M. Raymer (1982), Eighteen degree water variability, J. Mar. Res., 40, suppl., 757-775.

Tréguier, A.-M., O. Boebel, B. Barnier, and G. Madec (2003), Agulhas eddy fluxes in a 1/60 Atlantic model, Deep Sea Res., Part II, 50, $251-$ 280.

Ueyama, R., and B. Monger (2005), Wind-induced modulation of seasonal phytoplankton blooms in the North Atlantic derived from satellite observations, Limnol. Oceanogr., 50, 1820-1829.

Warren, B. A. (1972), Insensitivity of subtropical mode water characteristics to meteorological fluctuations, Deep Sea Res., 19, 1-19.

Williams, R. G., and M. J. Follows (1998), The Ekman transfer of nutrients and maintenance of new production over the North Atlantic, Deep Sea Res., Part I, 45, 461-489.

Williams, R. G., V. Roussenov, and M. J. Follows (2006), Nutrients streams and their induction into the mixed layer, Global Biogeochem. Cycles, 20, GB1016, doi:10.1029/2005GB002586.

Woods, J. (1985), The Physics of Thermocline Ventilation: Coupled Atmosphere-Ocean Models, edited by J. C. J. Nihoul, Elsevier, New York.

Worthington, L. (1959), The $18^{\circ}$ water in the Sargasso Sea, Deep Sea Res., $5,297-305$.

Worthington, L. (1976), On the North Atlantic Circulation, Johns Hopkins Oceanogr. Stud., vol. 6, Johns Hopkins Univ. Press, Baltimore, Md.

O. Aumont, Institut de recherche pour le Développement, Centre IRD de Bretagne, BP 70, F-29280 Plouzané, France.

A.-S. Krémeur, M. Lévy, and G. Reverdin, LOCEAN-IPSL, University of Paris 6, BC 100, F-75252 Paris CEDEX 05, France. (annesophie.kremeur@ gmail.com) 